\title{
ON THE GROWTH AND FEEDING OF YOUNG HERRING IN THE CLYDE
}

\author{
By S. M. Marshall, D.Sc., A. G. Nicholls, Ph.D. and \\ A. P. Orr, M.A., D.Sc., A.I.C. \\ Marine Station, Millport \\ (Text-figs. I-I2)

\begin{tabular}{|c|c|c|c|c|c|}
\hline \multicolumn{6}{|c|}{ CONTENTS } \\
\hline Collection & material & . & . & . & 427 \\
\hline Race deter & ation & . & 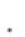 & & 429 \\
\hline Size and $\mathrm{g}$ & th & . & . & 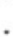 & 434 \\
\hline Weight . & . & 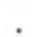 & . & & $43^{8}$ \\
\hline Chemical & position & . & & $\cdot$ & 442 \\
\hline Food and & relation $\mathrm{t}$ & the & an & & 445 \\
\hline Summary & . & . & . & . & 453 \\
\hline References & . & . & . & & 453 \\
\hline
\end{tabular}

In an earlier paper (Marshall, Nicholls \& Orr, 1937) the growth of the herring in the Clyde was followed from spawning to metamorphosis. The present paper gives the results of an attempt to continue this work from metamorphosis up to the formation of the first winter ring.

During the course of the work two distinct groups of herring were met with. Those of the first, which were obtained from July I936 to May 1937, were caught in Kames Bay and on Fairlie Sands; the second, of which only a few catches were taken, in 1937 and 1938 , were smaller and were caught offshore. As will be shown below, the second group is composed of herring which were spawned in the Clyde sea-area in spring and are therefore of the same origin as those discussed in the previous paper.

\section{COLLECTION OF MATERIAL}

Larvae which had been followed from hatching off Brown Head on the coast of Arran to metamorphosis in the mouth of Loch Fyne about the beginning of June 1935 disappeared thereafter. In spite of an intensive search of the area during the following months, both in sandy bays using a finemeshed shore seine and in deeper water using a Poole sprat trawl, very few were found. In July 1936, however, young herring about $80 \mathrm{~mm}$. long were captured in Kames Bay, a shallow sandy bay on the island of Cumbrae. From then on successful hauls were made at about weekly intervals in the same bay till the end of September when numbers became very small. There- 
after till the following May they could be caught near Hunterston Perch on Fairlie Sands on the Ayrshire coast. At this position the sand-flat shelves steeply down to a depth of several fathoms, and hauls were always made at low tide when it was possible to use the shore seine on the slope. The best hauls were taken about dusk or dawn on moonless or overcast nights. On several occasions both in Kames Bay and on Fairlie Sands the herring disappeared as soon as the moon rose.

Catches on Fairlie Sands were not obtained so regularly as in Kames Bay and it was sometimes necessary to make hauls on several nights before a catch was obtained. Sometimes an indication of herring was given by gannets diving, by the presence of seals or by hearing the fish break the surface. The catches were smaller after November 1936, and after May 1937 they were irregular. By the end of May the new brood of young herring appeared again in Kames Bay and these were followed for a few weeks to compare with the previous year's fish.

The number of herring in a haul with the fine-meshed shore seine varied very considerably. Sometimes several hauls were required to obtain sufficient fish for a sample (a few hundred), but occasionally many thousands were captured in a single haul.

Other types of gear were tried with varying degrees of success. A Saltash tuck seine with a fine-meshed bag proved unsuccessful in spite of being used immediately after the shore seine had made a successful haul. A Poole sprat trawl was uniformly unsuccessful even at times when herring were present in large numbers. A series of drift nets with mesh varying from 57 to 75 rows per yard was useful offshore, but since the shore seine provided an unselected sample the use of drift nets was discontinued.

For offshore work a sprat ring net similar to that used at Newhaven, in the Firth of Forth, was used and was successful at times when the herring could be located by means of phosphorescence in the water. Unfortunately the mesh in the bag of the net was too large ( 90 rows per yard) to retain all the smallest fish so that sampling for these was not accurate. Successful catches of the small offshore fish were made in July and August I937 in Loch Striven, the Kyles of Bute and round the Cumbrae, and in October 1937 and March 1938 in Loch Striven.

To find the fluctuations of numbers with time of night and to provide material for a study of the food over a night, a series of hauls was made at $2 \mathrm{hr}$. intervals in Kames Bay on August I4 I936 (Fig. I2 A). At 5 p.m. (B.S.T.), although it was full daylight and there were a number of bathers and small boats in the bay, 132 herring were caught in one haul; at 7 p.m. the number rose to 4000-5000. The best catch (estimated at over 10,000 fish) was obtained at 9 p.m., the time of sunset. After this catches decreased rapidly; at II p.m. when it was quite dark, there were 450 ; at I a.m., 8 ; at 3 a.m., I2. At 5 a.m. when dawn was breaking there was a slight increase to 293 , but by 7 a.m. there was a decrease again to 6 and hauls were discontinued. 


\section{RaCe Determination}

As has already been mentioned, the young herring captured in the Clyde belong to two different groups which may conveniently be described as inshore and offshore. The inshore fish were considerably larger than the offshore fish and it became necessary to find out whether two distinct races of herring were present, and if so which, if either, represented the Clyde spring-spawned fish.

In defining different races of herring, one of the most usual methods is to count the number of vertebrae in a representative sample of fish; the mean number is indicative of the race. Wood (1936) found the mean number of vertebrae in spring-spawning herring in the Clyde to vary between 57.03 and $57 \cdot 2$ I. It should be noted that Wood follows Williamson (I9I4) and Johansen (I9I9) in including the first segment of the terminal ossicle in the vertebral count. In this paper we have followed Orton (I9I6) and Ford (I928a) in excluding it. Four samples of adult Clyde herring taken in the autumn of 1937 and the spring of 1938 gave counts from 55.88 to $56 \cdot 06$, which shows a good agreement with Wood's figures when the necessary allowance of one vertebra is made. A statistical comparison (see Ford, I928a, p. 259) showed that these four samples agreed well with one another and with Wood's samples.

Counts were also made on samples of the young herring caught and it was found that the herring of the offshore group had a vertebral count varying from $55 \cdot 97$ to $56 \cdot 16$ showing agreement with the Clyde spring-spawned fish. Those caught in Kames Bay and on Fairlie Sands (the inshore group) belonged to a different race with a lower vertebral count varying from $55 \cdot 40$ to $55 \cdot 65$.

In Fig. I are shown percentage frequency graphs of the number of vertebrae based on the commercial catches of Clyde fish (A), the offshore samples of young herring (B), and the inshore samples (C). The results of the individual counts are given in Table I. It will be seen that whereas curves (A) and (B) show a sharp peak, as is typical of Wood's spring spawners, (C) is of a quite distinct type. There seems little doubt therefore that the offshore fish are Clyde spring-spawned herring. Similar counts to those of the offshore fish were obtained on the 1935 brood in three successive years (Table I, C). As premetamorphosis fish they were caught in Loch Fyne in I935 (May 30), as one year old fish in Kames Bay in 1936 (August Io), and as two year old fish in Millport Bay in I937 (May 26), and the vertebral counts were 56.07, 56.07 and $55^{\circ} 97$ respectively.

The curve shown by the inshore fish (C) is similar to Wood's autumnspawning type. There is, however, little evidence of any autumn spawning in the Clyde. Tow-nettings were taken for larvae and the gonads of adult fish examined in autumn, but no indication was obtained that any spawning takes place before March. Wood (I937, p. I8) believes that the Clyde "estuary" is a nursery for adolescent herring groups until they reach sexual maturity. 
It is possible therefore that the origin of these herring is to be sought outside the Clyde. Samples of adult herring were obtained from the North of Ireland fisheries in April and September 1938, and from the Isle of Man fisheries in April and July 1938. The first were spent and their vertebral count showed

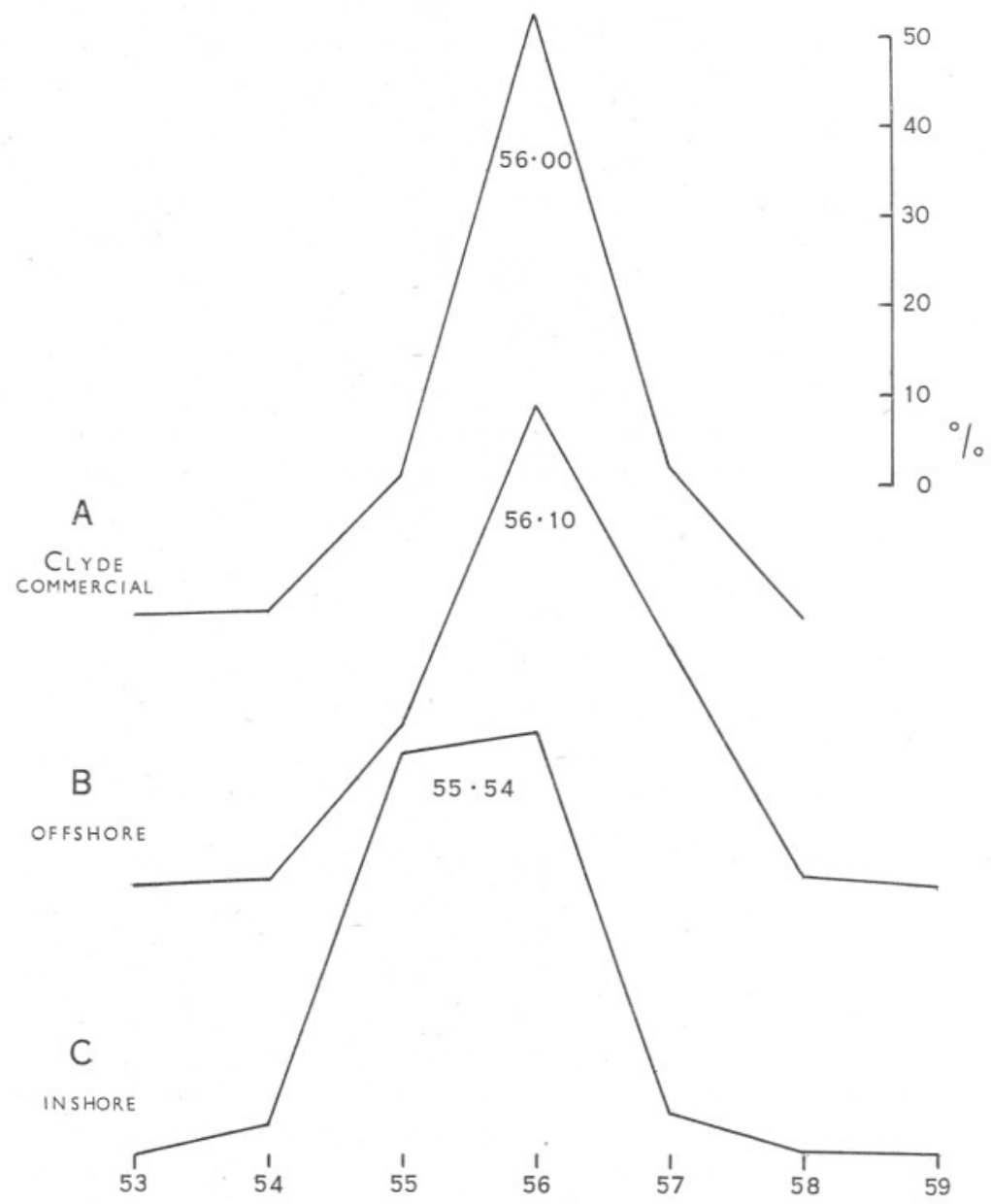

Fig. I. Percentage frequency distribution curves of vertebral counts.

the typical curve for spring-spawning herring (average number of vertebrae $55.97)$. The second were mostly full and showed the autumn-spawning type of curve (average number of vertebrae 55.63). The Isle of Man fish were spent in April and recovering spents at the beginning of July and showed the typical autumn-spawning type of curve (average number of vertebrae 55.49 and 55.53 in April and July respectively). A statistical comparison showed that the North of Ireland fish in September and both lots of Isle of Man fish agreed 


\section{TABLE I}

\section{A. Vertebral Counts of Inshore Herring}

\begin{tabular}{|c|c|c|c|c|c|c|c|c|c|c|c|c|}
\hline \multirow[b]{2}{*}{ Date } & \multirow{2}{*}{$\begin{array}{l}\text { No. of } \\
\text { fish }\end{array}$} & \multicolumn{8}{|c|}{ Percentage number of vertebrae } & \multirow[b]{2}{*}{60} & \multirow[b]{2}{*}{ Mean } & \multirow[b]{2}{*}{$\sigma$} \\
\hline & & 52 & 53 & 54 & 55 & 56 & 57 & 58 & 59 & & & \\
\hline I3-I 4 \& I 4. vii. 36 & 102 & . & . & $2 \cdot 0$ & $47 \cdot I$ & $44 \cdot I$ & $6 \cdot 9$ & . & . & $\ldots$ & $55 \cdot 56$ & 0.654 \\
\hline 20. vii. 36 & 106 & . & .. & 0.9 & $4 \mathrm{I} \cdot 5$ & $52 \cdot 8$ & 47 & $\cdots$ & . & . & $55.6 \mathrm{I}$ & 0.595 \\
\hline 27. vii. 36 & IO3 & . & . & $7 \cdot 8$ & $44 \cdot 7$ & $42 \cdot 7$ & $2 \cdot 9$ & I.O & . & $I \cdot O$ & $55 \cdot 49$ & 0.850 \\
\hline ro. viii. 36 & III & . & . & $2 \cdot 7$ & $5 \mathrm{I} \cdot 4$ & $4 I \cdot 5$ & $4 \cdot 5$ & $\ldots$ & . & $\cdots$ & $55 \cdot 48$ & 0.630 \\
\hline I4. viii. 36 & I09 & . & .. & 4.6 & $37 \cdot 6$ & $52 \cdot 3$ & $5 \cdot 5$ & $\cdots$ & $\cdots$ & $\cdots$ & $55 \cdot 59$ & 0.670 \\
\hline 31. viii. 36 & I IO & .. & . & $6 \cdot 4$ & $40 \cdot 9$ & $49 \cdot I$ & 3.6 & $\cdots$ & .. & $\cdots$ & 55.50 & 0.674 \\
\hline 23. ix. 36 & I I I & .. & .. & $4 \cdot 5$ & $48 \cdot 7$ & $42 \cdot 4$ & $4 \cdot 5$ & $\ldots$ & $\cdots$ & . & $55 \cdot 47$ & 0.658 \\
\hline 29. ix. 36 & I I I & $\cdots$ & $\cdots$ & $4 \cdot 5$ & $37 \cdot 8$ & $52 \cdot 3$ & $5 \cdot 4$ & $\cdots$ & . & . & 55.59 & 0.667 \\
\hline $5 . x \cdot 36$ & I IO & $\cdots$ & $\cdots$ & $3 \cdot 6$ & $46 \cdot 4$ & 43.6 & $5 \cdot 5$ & 0.9 & $\ldots$ & . & 55.54 & 0.700 \\
\hline I3. x. 36 & I Io & $\cdots$ & $\cdots$ & I. 8 & $37 \cdot 3$ & 55.5 & $4 \cdot 6$ & 0.9 & $\cdots$ & $\cdots$ & 55.65 & 0.642 \\
\hline 28. x: 36 & IIO & $\cdots$ & $\cdots$ & $\mathrm{I} \cdot 8$ & $49^{\circ} I$ & $42 \cdot 7$ & 6.4 & $\cdots$ & $\cdots$ & $\cdots$ & 55.54 & 0.645 \\
\hline 3. xi. 36 & I IO & . & . & 0.9 & 40.9 & $5 \mathrm{I} \cdot 8$ & $6 \cdot 4$ & . & $\ldots$ & $\cdots$ & 55.64 & 0.617 \\
\hline I3. xi. 36 & I IO & .. & .. & $2 \cdot 7$ & $56 \cdot 4$ & $39 \cdot I$ & $\mathrm{I} \cdot 8$ & $\cdots$ & $\cdots$ & $\cdots$ & $55 \cdot 40$ & 0.578 \\
\hline 27. xi. 36 & 109 & $\cdots$ & $\cdots$ & $I \cdot 8$ & $43 \cdot I$ & $5 \mathrm{I} \cdot 4$ & $3 \cdot 7$ & . & $\ldots$ & $\ldots$ & 55.57 & 0.599 \\
\hline II. xii. 36 & Iro & . & . & $4 \cdot 6$ & $42 \cdot 7$ & $49 \cdot I$ & $2 \cdot 7$ & 0.9 & $\ldots$ & . & 55.53 & 0.673 \\
\hline 28. xii. 36 & Iro & .. & $\cdots$ & $5 \cdot 5$ & 50.9 & 40.9 & $2 \cdot 7$ & . & .. & $\cdots$ & $55 \cdot 4 \mathrm{I}$ & 0.640 \\
\hline $12 \& 13.1 .37$ & I IO & .. & $\cdots$ & 3.6 & $39 \cdot 1$ & $5 I \cdot 8$ & $5 \cdot 5$ & $\ldots$ & .. & $\cdots$ & 55.59 & 0.654 \\
\hline 9. ii. 37 & Iro & . & . & $5 \cdot 5$ & $4 I \cdot 8$ & $47 \cdot 3$ & $5 \cdot 5$ & $\cdots$ & . & $\cdots$ & 55.53 & 0.687 \\
\hline I5. iii. 37 & I Io & .. & $\cdots$ & $5 \cdot 5$ & $4 \mathrm{I} \cdot 8$ & $45 \cdot 5$ & $6 \cdot 4$ & 0.9 & .. & $\cdots$ & $55 \cdot 55$ & 0.737 \\
\hline 29. iii. 37 & I IO & .. & .. & $4 \cdot 6$ & $35 \cdot 5$ & $55 \cdot 5$ & $4 \cdot 6$ & $\ldots$ & .. & $\ldots$ & 55.60 & 0.653 \\
\hline I3. iv. 37 & 79 & .. & .. & $\mathrm{I} \cdot 3$ & $5 \mathrm{I} \cdot 9$ & $40 \cdot 5$ & $6 \cdot 3$ & .. & . & $\cdots$ & $55 \cdot 52$ & 0.638 \\
\hline 28-29. iv. 37 & IIO & . & .. & 0.9 & $48 \cdot 2$ & $47 \cdot 3$ & $3 \cdot 6$ & $\cdots$ & . & $\ldots$ & $55 \cdot 54$ & 0.585 \\
\hline 13.v. 37 & I IO & .. & .. & $3 \cdot 6$ & 43.6 & $45 \cdot 5$ & $6 \cdot 4$ & 0.9 & . & $\cdots$ & 55.57 & 0.710 \\
\hline 27. v. 37 & 109 & $\ddot{n}$ & $\cdots$ & . & $46 \cdot 8$ & $49 \cdot 5$ & $3 \cdot 7$ & .. & .. & $\cdots$ & $55 \cdot 57$ & 0.567 \\
\hline 21, $22 \&$ 25. vi. 37 & I 10 & 0.9 & .. & 0.9 & 40.0 & 55.5 & $2 \cdot 7$ & $\ldots$ & .. & $\cdots$ & $55 \cdot 57$ & 0.656 \\
\hline I5. vii. 37 & I Io & .. & . & $4 \cdot 6$ & $5 \mathrm{I} \cdot 8$ & 40.9 & $\mathrm{I} \cdot 8$ & 0.9 & . & $\cdots$ & $55 \cdot 43$ & 0.656 \\
\hline 28. vii. 37 & 83 & . & .. & $2 \cdot 4$ & $49 \cdot 4$ & $42 \cdot 2$ & 6.0 & $\ldots$ & .. & $\cdots$ & $55 \cdot 52$ & $0.65 \mathrm{I}$ \\
\hline
\end{tabular}

From 23. ix. 36 to 13. iv, 37 inclusive and on 13. v. 37 the herring were taken from Fairlie Sands, and on the remaining dates from Kames Bay.

\section{B. Vertebral Counts of Offshore Herring}

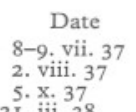

5. x. 37
I. iii. 38
Source

Loch Striven The Tan Loch Striven

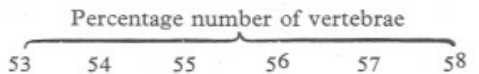

53

$\begin{array}{lllllll}53 & 54 & 55 & 56 & 57 & 58 & \text { Mean }\end{array}$

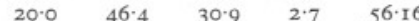

$\begin{array}{llllll}1.8 & 16.4 & 50.0 & 30.9 & 0.9 & 56.13\end{array}$

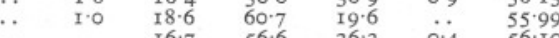

$\sigma$

0.773

0.756

0.652

\section{Vertebral Counts of 1935 Brood Fish}

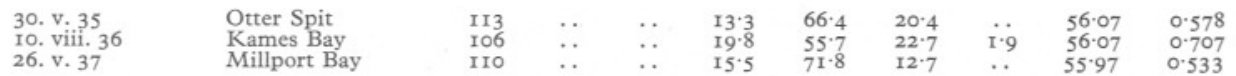

\section{Vertebral Counts of Commercial SAmples}

\begin{tabular}{|c|c|c|c|c|c|c|c|c|c|c|}
\hline I5. x. 37 & Clyde & 100 & $\cdots$ & $\cdots$ & $12 \cdot 0$ & $73 \cdot 0$ & 15.0 & .. & 56.03 & $0.52 \mathrm{I}$ \\
\hline 9. xi. 37 & Clyde & I08 & .. & $\therefore$ & 26.9 & $58 \cdot 4$ & I 4.8 & . & 55.88 & 0.637 \\
\hline ro. iii. 38 & Clyde (Brown Head) & I IO & . & 0.9 & II. 8 & $70 \cdot 9$ & I6. 4 & $\therefore$ & 56.03 & 0.566 \\
\hline I6. iii. 38 & $\begin{array}{l}\text { Clyde (Ballantrae } \\
\text { Banks) }\end{array}$ & IIO & . & 0.9 & $12 \cdot 7$ & $65 \cdot 5$ & 20.9 & $\cdots$ & 56.06 & $0.6 \mathrm{ro}$ \\
\hline $\begin{array}{l}\text { 8. iv. } 38 \\
\text { I3 \& } 19 . \text { iv. } 38\end{array}$ & $\begin{array}{l}\text { Isle of Man } \\
\text { North of Ireland }\end{array}$ & $\begin{array}{l}217 \\
183\end{array}$ & $\begin{array}{l}0.5 \\
\cdots\end{array}$ & $\begin{array}{l}5 \cdot 1 \\
\cdots\end{array}$ & $\begin{array}{l}45 \cdot 6 \\
20 \cdot 8\end{array}$ & $\begin{array}{l}43 \cdot 3 \\
62 \cdot 8\end{array}$ & $\begin{array}{r}5 \cdot 1 \\
15 \cdot 3\end{array}$ & $\begin{array}{l}0.5 \\
1 \cdot 1\end{array}$ & $\begin{array}{l}55.49 \\
55.97\end{array}$ & $\begin{array}{l}0.715 \\
0.637\end{array}$ \\
\hline
\end{tabular}


with the inshore young herring from the Clyde; in addition they agree fairly well with summer-spawned Isle of Man herring examined by el Saby (I932).

Because of their proximity to one another, it might be expected that the two groups of young herring would be mixed in the catches. The distinction between the two groups of fish, however, is sharp and it seems improbable that any appreciable intermixture takes place. In July when both types of fish were caught about the same time, there was hardly any overlapping in the

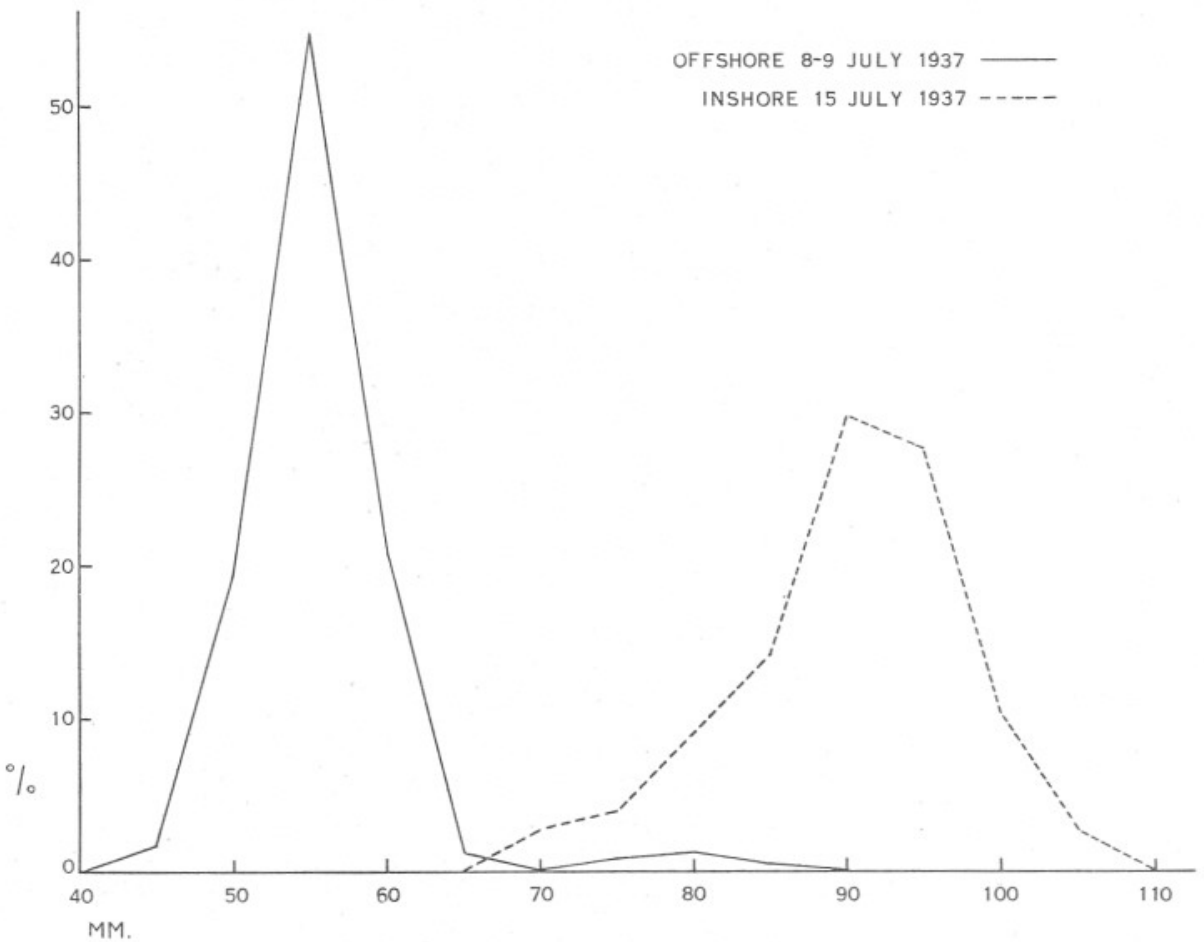

Fig. 2. Percentage frequency distribution curves of lengths for comparison of inshore and offshore young herring.

size frequency distribution curve (see Table II and Fig. 2). The vertebral counts also are distinct in the groups and, within each group, show statistical agreement. Either then the two groups of fish keep apart or the degree of intermixture is comparatively constant. This last possibility is ruled out for the following reason. Since the offshore herring, which had a high vertebral count, are considerably smaller than the inshore fish, it would be expected that if mixing were taking place, the smaller fish of any sample would have a higher average number of vertebrae than the sample as a whole. No such difference actually exists so that we may conclude that the two groups keep apart and that mixture is negligible. 


\section{Table II. Length Measurements of Inshore Herring}

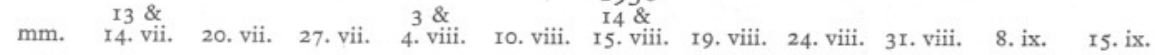

\begin{tabular}{|c|c|c|c|c|c|c|c|c|c|c|c|}
\hline & & & & & & & & & & & \\
\hline 55 & $\ddot{z}$ & I & 2 & $\because$ & $\cdots$ & $\cdots$ & $\cdots$ & . & . & . & $\cdots$ \\
\hline $\begin{array}{l}60 \\
65\end{array}$ & $\begin{array}{r}2 \\
10\end{array}$ & I & I & I & . & . & $\cdots$ & $\cdots$ & $\cdots$ & $\cdots$ & $\cdots$ \\
\hline $\begin{array}{l}65 \\
70\end{array}$ & $\begin{array}{l}\text { IO } \\
17\end{array}$ & I & $\cdots$ & I & . & . & $\because$ & $\cdots$ & .. & . & $\cdots$ \\
\hline $\begin{array}{l}70 \\
75\end{array}$ & $\begin{array}{l}17 \\
30\end{array}$ & 13 & 2 & 2 & $\cdots$ & 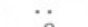 & 2 & $\cdots$ & $\cdots$ & $\cdots$ & $\cdots$ \\
\hline $\begin{array}{l}75 \\
80\end{array}$ & $\begin{array}{l}30 \\
90\end{array}$ & 56 & 6 & 12 & 3 & 9 & 2 & $\cdots$ & $\cdots$ & $\cdots$ & $\ddot{4}$ \\
\hline 85 & $\begin{array}{r}90 \\
124\end{array}$ & & $2 I$ & 47 & 8 & 20 & 9 & $\cdots$ & $\cdots$ & $\cdots$ & $\begin{array}{r}4 \\
8\end{array}$ \\
\hline 90 & $\begin{array}{r}124 \\
26\end{array}$ & I55 & 94 & 109 & Is & 32 & 4 & I & $\mathrm{I}$ & . & I8 \\
\hline 95 & $\begin{array}{r}26 \\
I\end{array}$ & 226 & 294 & I75 & 28 & 79 & 7 & 4 & $\cdots$ & $\cdots$ & 38 \\
\hline 100 & . & 92 & 155 & I34 & 62 & 128 & I & 9 & $\cdots$ & 4 & 44 \\
\hline ros & $\cdots$ & 7 & 44 & 33 & 130 & 238 & 3 & 38 & 2 & I 4 & 73 \\
\hline IIo & . & $\cdots$ & 3 & 6 & I $8 \mathrm{I}$ & 397 & 5 & 80 & I4 4 & 29 & 97 \\
\hline II5 & . & $\because$ & $\cdots$ & $\cdots$ & 67 & 245 & 3 & IIO & 24 & 71 & I 22 \\
\hline 120 & . & $\because$ & $\cdots$ & $\cdots$ & 7 & 60 & $\because$ & 78 & 53 & 77 & 75 \\
\hline 125 & . & $\because$ & $\cdots$ & $\cdots$ & . & I & I & 39 & 85 & $8 \mathrm{I}$ & 23 \\
\hline I30 & $\cdots$ & $\because$ & $\because$ & $\because$ & $\because$ & $\cdots$ & $\cdots$ & 2 & 83 & 47 & 5 \\
\hline I35 & $\cdots$ & . & $\because$ & $\cdots$ & $\cdots$ & $\cdots$ & * & I & I6 & I7 & 3 \\
\hline I 40 & . & . & 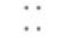 & $\cdots$ & $\cdots$ & $\cdots$ & $\cdots$ & . & $\cdots$ & I & I \\
\hline I 45 & $\cdots$ & $\cdots$ & 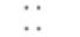 & $\because$ & $\because$ & $\cdots$ & $\cdots$ & $\cdots$ & $\cdots$ & $\cdots$ & $\cdots$ \\
\hline 150 & . & .. & $\because$ & $\because$ & $\cdots$ & $\cdots$ & $\cdots$ & $\cdots$ & $\cdots$ & $\cdots$ & $\cdots$ \\
\hline I5s & $\cdots$ & . & 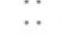 & $\cdots$ & $\cdots$ & $\cdots$ & $\cdots$ & $\cdots$ & $\cdots$ & $\cdots$ & $\cdots$ \\
\hline 160 & $\cdots$ & . & $\cdots$ & $\because$ & $\because$ & $\because$ & $\cdots$ & $\cdots$ & $\cdots$ & $\cdots$ & $\cdots$ \\
\hline 165 & $\cdots$ & . & . & $\because$ & $\because$ & $\cdots$ & $\cdots$ & $\cdots$ & $\cdots$ & $\cdots$ & $\cdots$ \\
\hline 170 & . & . & . & $\because$ & $\cdots$ & $\cdots$ & $\cdots$ & . & $\cdots$ & $\cdots$ & $\cdots$ \\
\hline Total & 300 & 638 & 622 & $\begin{array}{r}00 \\
520\end{array}$ & $\cdots$ & $\because$ & $\cdots$ & $\ddot{v}$ & $\cdots$ & $\cdots$ & 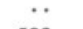 \\
\hline Median & $85 \cdot 1$ & $90 \cdot 2$ & $93 \cdot 2$ & & 501 & 1209 & 37 & 362 & 278 & $34 \mathrm{I}$ & 503 \\
\hline Average & 83.4 & $88 \cdot 4$ & $92 \cdot 5$ & $\begin{array}{l}92 \cdot 4 \\
9 I \cdot 7\end{array}$ & ros. I & $107 \cdot$ I & $91^{\circ} 0$ & I I 2.4 & 1227 & I I 8.8 & I09:2 \\
\hline & & & & & 103.4 & $105 * 4$ & 920 & III.6 & $\mathrm{I} 2 \mathrm{I} \cdot \mathrm{I}$ & $117 \cdot 8$ & $107^{\circ} \cdot 2$ \\
\hline & & & & & & I936 & & & & & \\
\hline $\begin{array}{c}\mathrm{mm} . \\
55\end{array}$ & 23. $1 x$ & 29. 1x. & $5 \cdot x$ & I3. X. & 28. x. & 3. xi. & I I. xi. & I3. xi. & 27. xi. & I r. xii. & 28. xii. \\
\hline $\begin{array}{l}55 \\
60\end{array}$ & $\because$ & $\cdots$ & $\cdots$ & $\cdots$ & $\cdots$ & $\cdots$ & $\cdots$ & . & $\cdots$ & $\cdots$ & $\cdots$ \\
\hline 65 & 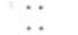 & $\cdots$ & $\cdots$ & $\cdots$ & $\cdots$ & $\cdots$ & $\cdots$ & $\cdots$ & $\cdots$ & $\cdots$ & $\cdots$ \\
\hline 70 & $\because$ & $\because$ & $\cdots$ & $\cdots$ & $\cdots$ & $\cdots$ & $\cdots$ & $\cdots$ & $\cdots$ & $\cdots$ & $\cdots$ \\
\hline 75 & $\cdots$ & 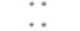 & 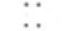 & $\because$ & $\cdots$ & $\cdots$ & $\cdots$ & $\cdots$ & $\cdots$ & $\cdots$ & $\cdots$ \\
\hline 80 & . & . & $\because$ & $\because$ & $\because$ & $\because$ & $\because$ & $\because$ & $\cdots$ & $\cdots$ & $\because$ \\
\hline 85 & $\cdots$ & . & . & . & & $\cdots$ & $\because$ & $\because$ & $\because$ & $\because$ & $\because$ \\
\hline 90 & . & $\cdots$ & $\cdots$ & $\cdots$ & 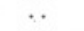 & $\cdots$ & 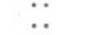 & $\because$ & $\therefore$ & $\because$ & 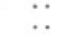 \\
\hline 95 & $\because$ & $\cdots$ & $\cdots$ & $\cdots$ & $\cdots$ & .. & I & . & I & . & . \\
\hline 100 & 2 & $\cdots$ & $\because$ & $\cdots$ & . & $\cdots$ & $\cdots$ & $\cdots$ & $\cdots$ & $\cdots$ & I \\
\hline I05 & I & I & I & $\cdots$ & $\cdots$ & $\cdots$ & I & . & I & $\cdots$ & I \\
\hline IIO & 8 & 6 & $\cdots$ & I & $\cdots$ & I & 3 & $\cdots$ & 4 & $\cdots$ & 3 \\
\hline II 5 & 29 & 38 & 4 & 7 & I & 2 & I7 & 2 & 12 & 3 & 26 \\
\hline 120 & 74 & 64 & 13 & 45 & 4 & I I & 58 & I3 & 46 & 16 & 49 \\
\hline 125 & 94 & 98 & 80 & 142 & 46 & 55 & 90 & 56 & I08 & 65 & 109 \\
\hline 130 & 32 & 65 & 129 & 218 & 94 & 62 & 40 & $9 \mathrm{I}$ & 127 & 120 & $8 \mathrm{I}$ \\
\hline I35 & IO & I6 & 58 & 169 & 88 & 70 & I8 & 65 & 74 & 53 & 40 \\
\hline 140 & $\cdots$ & $\cdots$ & II & I9 & 46 & 35 & 6 & 38 & $2 I$ & 36 & 8 \\
\hline I 45 & $\cdots$ & $\cdots$ & $\cdots$ & I & 7 & I3 & I & 20 & I I & $2 I$ & I \\
\hline I50 & $\cdots$ & $\cdots$ & $\cdots$ & $\cdots$ & $\cdots$ & 2 & $\because$ & $\cdots$ & 2 & 5 & $\cdots$ \\
\hline I 55 & $\cdots$ & $\cdots$ & $\cdots$ & $\cdots$ & $\cdots$ & $\cdots$ & I & $\cdots$ & $\cdots$ & 2 & $\cdots$ \\
\hline 160 & $\cdots$ & $\cdots$ & $\cdots$ & $\cdots$ & $\cdots$ & $\cdots$ & $\cdots$ & $*$ & $\cdots$ & $\cdots$ & $\cdots$ \\
\hline 165 & $\cdots$ & $\cdots$ & $\cdots$ & $\cdots$ & $\cdots$ & $\cdots$ & $\cdots$ & $\cdots$ & $\cdots$ & $\cdots$ & $\cdots$ \\
\hline I70 & $\cdots$ & $\ddot{0}$ & 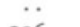 & $\cdots$ & $\ddot{i}$ & $\cdots$ & $\cdots$ & $\ddot{\theta}$ & $\cdots$ & $\because$ & $\because$ \\
\hline $\begin{array}{l}\text { Total } \\
\text { Median }\end{array}$ & 250 & 288 & 296 & 602 & 286 & $25 \mathrm{I}$ & 236 & 285 & 407 & 321 & 319. \\
\hline $\begin{array}{l}\text { Median } \\
\text { Average }\end{array}$ & $\begin{array}{l}\text { I25.8 } \\
\text { I } 24.8\end{array}$ & $\begin{array}{l}126.8 \\
125.8\end{array}$ & $\begin{array}{l}\text { I3I.8 } \\
\text { I } 3 I \cdot 2\end{array}$ & 132.8 & 134.9 & 134.5 & I $27^{\circ} \mathrm{I}$ & 133.7 & $I_{3} \mathrm{I} \cdot \mathrm{I}$ & 133.3 & $\begin{array}{l}128 \cdot 4 \\
I 28 \cdot I\end{array}$ \\
\hline Average & & 125.8 & $I_{3} I_{2} \cdot 2$ & I3I.7 & 134.6 & I33.9 & I 26.8 & I33.9 & I30.8 & I 33.9 & I $28 \cdot I$ \\
\hline
\end{tabular}

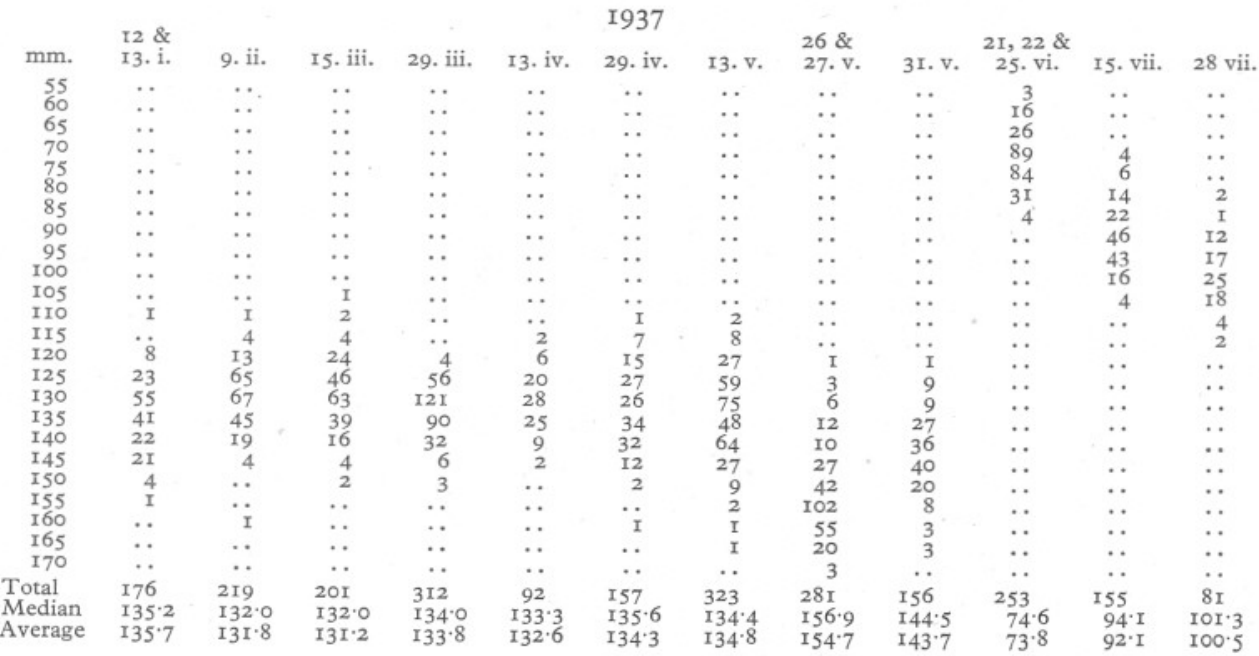


On two occasions (August Io 1936 and May 26 and 27 I937) offshore and inshore herring were obtained in numbers in the same hauls. On each occasion, however, they belonged to different year groups, as was discovered by scale examination, and the older fish were always offshore fish. These are smaller than inshore fish of the same age and in both sets of hauls were of similar size to inshore fish of the preceding year class. This mixture then was probably due to the tendency of herring of similar size to shoal together irrespective of age (Ford, I928b, p. 29I). In the catches from Kames Bay and Fairlie Sands it was usual to find a few fish belonging to the previous year class. These were omitted from the samples and they were never numerous enough for reliable size measurements or vertebral counts.

A considerable number of the backbones examined $(25 \%$ in the inshore fish and $19 \%$ in the offshore fish) showed complex vertebrae, i.e. vertebrae which, although the centrum shows no sign of division, have double spines dorsally, ventrally or both (Ford, 1933). These complex segments are not uncommon among herring and if they are counted as one vertebra the vertebral counts are too low. It has been found (Kändler, I932; Ford, I937) that if they are counted as one and a half vertebrae the normal average is obtained, and our results confirm this. The difference between the average of those with normal and those with abnormal vertebrae (when the latter are counted as one) was in inshore fish 0.49 and in offshore fish 0.46 . In Table I, however, the complex vertebrae are given the value of one. Fused vertebrae, which were very rare, are given their full value.

\section{SIZE AND GROWTH}

From each catch a sample of fish, at least 250 if possible, was taken and the length measured from the tip of the snout to the tip of the longest caudal fin ray on the ventral fluke. The fish were measured within an hour or two of capture on nearly all occasions, since it was found that standing overnight or fixation in formalin caused a shrinkage amounting to several millimetres.

Inshore herring. The results of the measurements of these fish are given in Table II and Figs. 3 and 4. In Fig. 3 are shown the median lengths of the samples of inshore and offshore herring. The upper curve which is that for the inshore herring shows that there was an increase in length from the first observation in 1936 (July) till the middle of October 1936 amounting to just over $50 \mathrm{~mm}$. giving an average weekly increase of about $3.5 \mathrm{~mm}$. This is slightly greater than the weekly size increment in premetamorphosis Clyde spring-spawned herring. From the beginning of November 1936 until the beginning of April 1937 there was no increase in the median length, but fish caught at the end of May 1937 were considerably larger. The catches made during April were small and it is doubtful when the new year's growth actually started. On April I 3 a few of the herring and on May I4 the majority showed the new winter ring at the edge of the scale. In June and July I937 
several samples of the new brood of inshore herring were obtained and their median lengths are also shown on the curve.

In Fig. 4 are shown the size frequency distribution curves of the samples grouped in fortnightly periods, omitting for simplicity the majority of the winter samples when there was no growth. The curves show the gradual increase in length up to October and the new growth in spring. The new brood of I937 which was caught earlier than in I936 is also shown. The smallest fish caught, nine in number, were taken on May 27 I937 and varied from 47 to $56 \mathrm{~mm}$. in length. The curves show that in general the samples

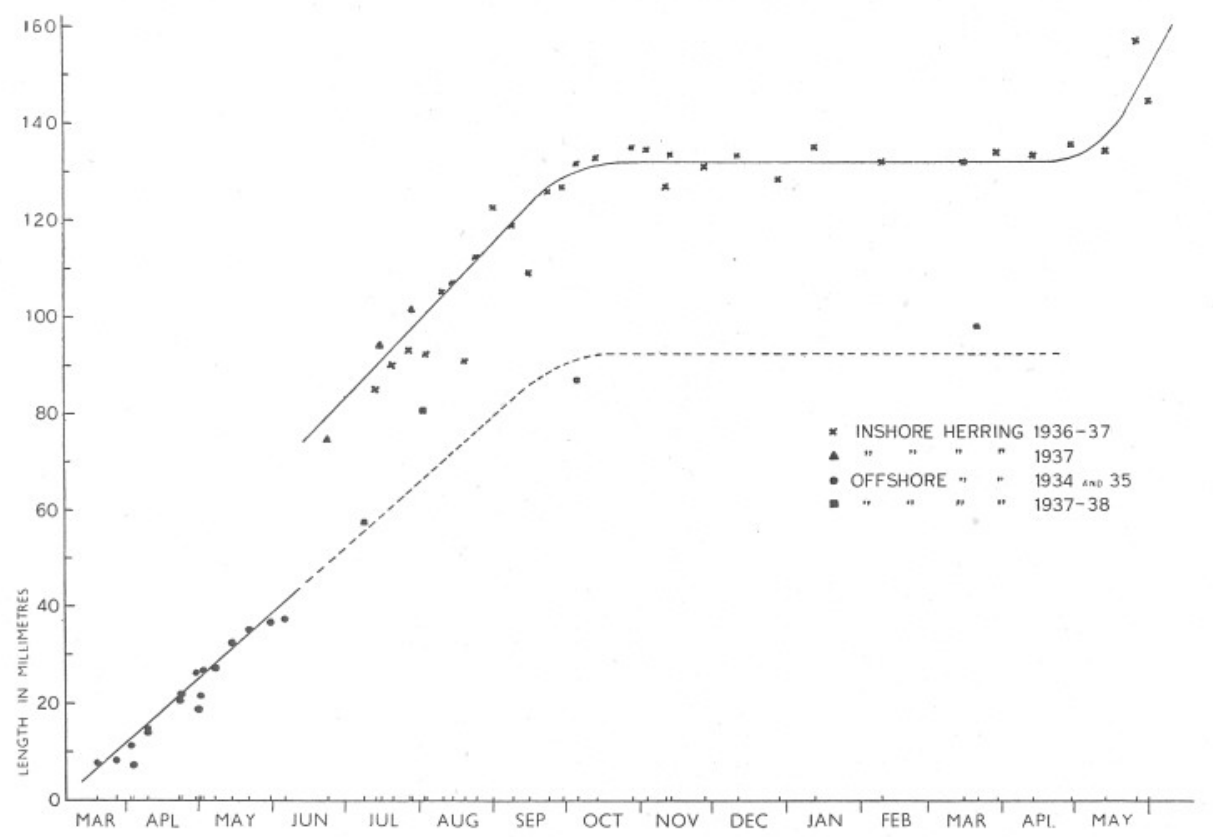

Fig. 3. Median lengths of inshore and offshore young herring, showing rate of growth.

were homogeneous and that the size range within a sample did not increase much during the year.

Offshore fish. Only four catches of offshore fish in their first year were obtained, two during the growth period, one near the end of the growth period, and one near the end of the winter non-growing period. The points representing median lengths fit on an extension of the growth curve for premetamorphosis Clyde herring taken in I935 and run parallel to but well below that for the inshore fish (Table III and Fig. 3). Thus in July I937 the inshore fish had a median length of $94^{\circ} \mathrm{I} \mathrm{mm}$. and the offshore fish $57.6 \mathrm{~mm}$., while in March 1938, when they were forming their first winter ring, the inshore fish had a median length of about $132 \mathrm{~mm}$. and the offshore about $98 \mathrm{~mm}$. The size given for the offshore fish is probably on the large side since, 


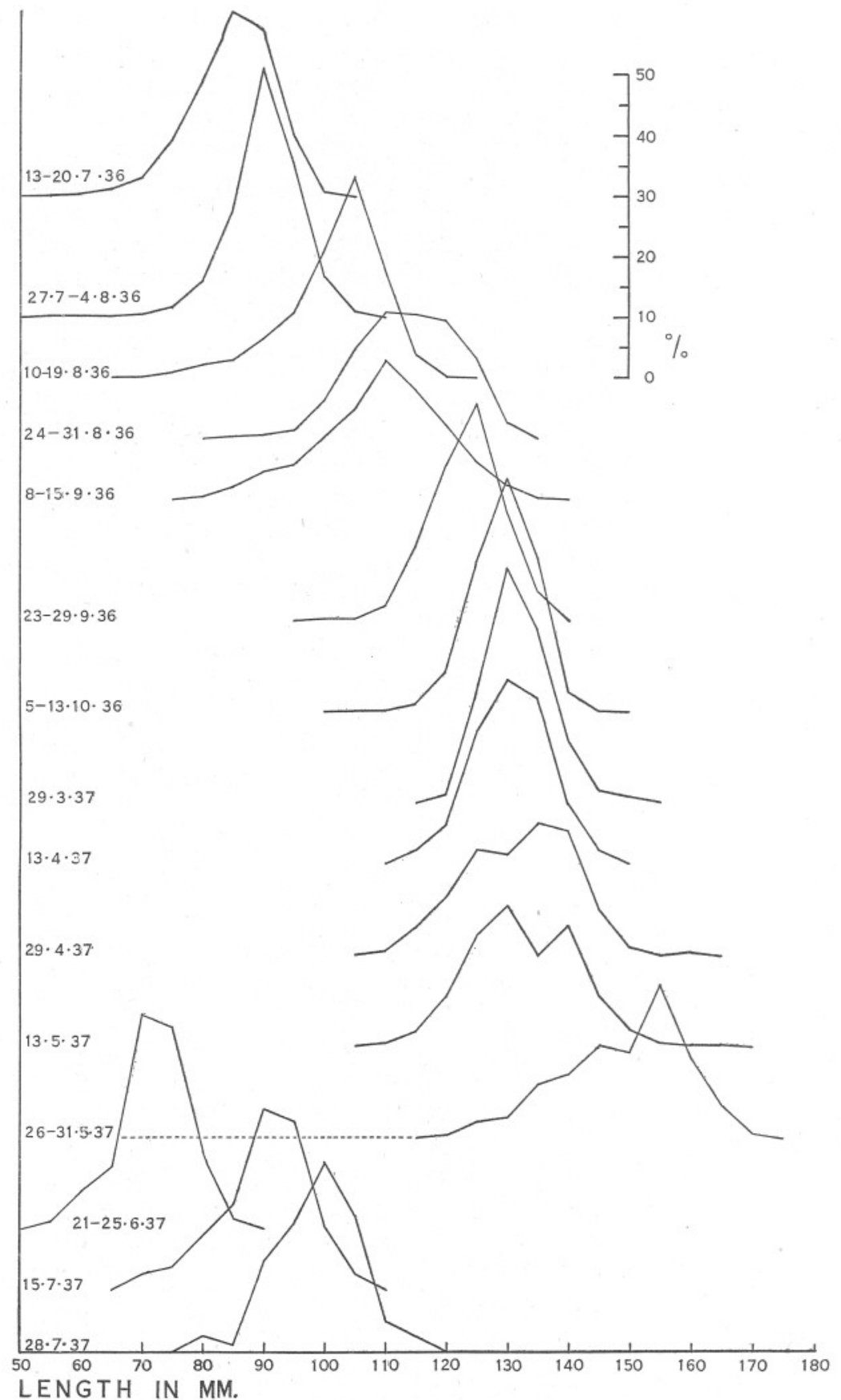

Fig. 4. Percentage frequency distribution curves for lengths of inshore herring, grouped in fortnightly periods. 
as mentioned above, a proportion escaped through the meshes of the net. The I935 brood of Clyde fish appeared again in the catches of 1936 (August IO) and I937 (May 26 and 27); their median lengths on these dates were I3I.3 and $164.4 \mathrm{~mm}$. respectively.

Since the inshore and offshore herring differ considerably in length at the time the first winter ring is formed, it is possible to differentiate between the two groups at any later stage. If we assume that the rate of growth of the scale is proportional to the rate of growth of the fish (Lea, I9IO), we can, by measurements on the scale, calculate the size of the fish at the end of each year's growth.

\begin{tabular}{|c|c|c|c|c|}
\hline $\mathrm{mm}$. & 8,9 . vii. 37 & 2. viii. 37 & $5 \cdot x \cdot 37$ & 21. iii. $3^{8}$ \\
\hline $\begin{array}{l}45 \\
50\end{array}$ & $\begin{array}{r}4 \\
48\end{array}$ & .. & . & . \\
\hline $\begin{array}{l}50 \\
55\end{array}$ & $\begin{array}{r}48 \\
136\end{array}$ & .. & ${ }^{\prime}$ & .. \\
\hline 60 & $5 \mathrm{I}$ & .. & .. & .. \\
\hline 65 & 3 & . & 2 & .. \\
\hline 70 & .. & 5 & I & .. \\
\hline 75 & 2 & 135 & I4 & 2 \\
\hline 80 & 3 & 167 & 82 & I4 \\
\hline 85 & I & 32 & 93 & 43 \\
\hline 90 & .. & 2 & 56 & $4 \mathrm{I}$ \\
\hline 95 & .. & .. & I8 & 39 \\
\hline 100 & . & .. & 9 & 42 \\
\hline 105 & . & .. & 7 & 36 \\
\hline I IO & .. & .. & Io & I9 \\
\hline II 5 & .. & .. & 6 & Io \\
\hline 120 & .. & .. & .. & 4 \\
\hline 125 & . & . & I & .. \\
\hline $\begin{array}{l}\text { Total } \\
\text { Median }\end{array}$ & 248 & $\begin{array}{l}34 \mathrm{I} \\
80 \cdot 7\end{array}$ & $\begin{array}{l}300 \\
87.0\end{array}$ & $\begin{array}{l}250 \\
08.2\end{array}$ \\
\hline Average & $\begin{array}{l}57 \cdot 6 \\
57 \cdot 6\end{array}$ & $\begin{array}{l}80.7 \\
80.4\end{array}$ & $\begin{array}{l}87.0 \\
88.9\end{array}$ & $\begin{array}{l}90.2 \\
98 \cdot I\end{array}$ \\
\hline
\end{tabular}

Scales were taken from each fish of the measured samples of Clyde, North of Ireland and Isle of Man adult herring and the size when the first winter ring was laid down measured, using the technique described by Ford (I928a). The average size of the herring in the four commercial catches from the Clyde fishery at the time of formation of the first winter ring $\left(l_{1}\right)$ was found to vary between 9I $\mathrm{mm}$. and I IO $\mathrm{mm}$. This compares with the average winter length of $93 \mathrm{~mm}$. estimated for offshore herring (Fig. 3). The commercial samples from the North of Ireland fisheries gave average $l_{1}$ values of $\mathrm{I} 2 \mathrm{I} \mathrm{mm}$. and I $22 \mathrm{~mm}$. Those from the Isle of Man fishery gave average $l_{1}$ values of $122 \mathrm{~mm}$. and $\mathrm{I} 20 \mathrm{~mm}$., figures above those obtained from the Clyde commercial catches and the Clyde offshore fish, and nearer that for the Clyde inshore young herring (I32 mm., Fig. 3). The results are not conclusive but further confirm the Clyde origin of the offshore fish and lend some support to the possibility that the inshore herring may have originated in the Isle of Man or North 0 Ireland grounds as was suggested by the vertebral counts.

Information on the rate of growth of herring during their first year is rather meagre. Among the earliest records are those of Meyer (I878) on spring- 
spawned herring in the Baltic. The rate of growth found by him for the period June II to November I4 $(2.5 \mathrm{~mm}$. per week) is lower than that found for Clyde spring-spawned herring (offshore type). On the other hand, at the end of the first year the Baltic herring reached a length of $138 \mathrm{~mm}$., whereas the Clyde spring-spawned herring measured only $98 \mathrm{~mm}$. The discrepancy is due to the Baltic herring growing during the winter, whereas those in the Clyde do not. Ford (I928c) measured the rate of growth of young herring from the Tamar and Lynher estuaries during their first year. The spawning at Plymouth in 1926-27 extended from October to March, so that the difference in age between the youngest and oldest might be several months. The median length of the Tamar fish on May 26 was $55.9 \mathrm{~mm}$. and on October $7 \mathrm{I2} 7^{.} \mathrm{I} \mathrm{mm}$., giving an average weekly increment during the growth period of $3.2 \mathrm{~mm}$. which is close to that for the inshore Clyde fish $(3.5 \mathrm{~mm}$.). Similarly the length during the winter non-growing period was about $124 \mathrm{~mm}$. in the Tamar fish as against $132 \mathrm{~mm}$. for the inshore fish in the Clyde.

\section{WEIGHT}

Of the herring caught, samples at definite sizes were weighed at intervals throughout the year. The sizes chosen were at approximately $5 \mathrm{~mm}$. intervals over the whole size range in each sample. The fish were usually weighed fresh after removal of adherent moisture and then dried to constant weight at $105^{\circ} \mathrm{C}$. The results of the dry weight determinations are shown in Table IV and Fig. 5. It is found that the weights of the inshore herring fall into two groups, (a) those of the growing period from July 4 I 936 to November 27 I936 and from April 291937 to May 27 1937, and (b) those of the winter period (in the intervening months) when growth had stopped. The relation between the dry weight in $\mathrm{gm}$. (W) and the length in $\mathrm{mm}$. $(L)$ during the growing period is given by the equation $W=0.000000258 L^{3.37}$, and during the winter period by $W=0.0000001095 L^{3.47}$. For adult herring from the English Channel, Fraser (I93I) using the wet weight determinations of Orton (I9I6) found $W=0.00000337 L^{3 \cdot 149}$.

For the Clyde inshore herring, the weight of the fresh fish fell only slightly during the non-growing period, but the water content was relatively higher and the fat content relatively lower so that there was a fall in dry weight as is seen in Table IV and Fig. 5. When growth began again in the spring, the fat content rose, the water content fell, and the points come once more on the upper curve. Similar conditions in adult herring have been described by Lea (I9II). Fig. 6 shows the relationship between the logarithms of the weights and the logarithms of the lengths for growing and non-growing periods. The points obviously lie on two straight lines, the equations for which (given above) were derived by calculation from the data.

The transition from the curve for the growing period to that for the nongrowing period is shown in the weights of herring on February 9 (Table IV). 
The points representing the weights of the smaller herring lie on or near the upper curve of Fig. 5, while those for the larger herring lie on or near the lower. Thus the larger herring reach winter weight conditions in advance of the smaller herring. Similarly on April 29 the weights of the smaller herring

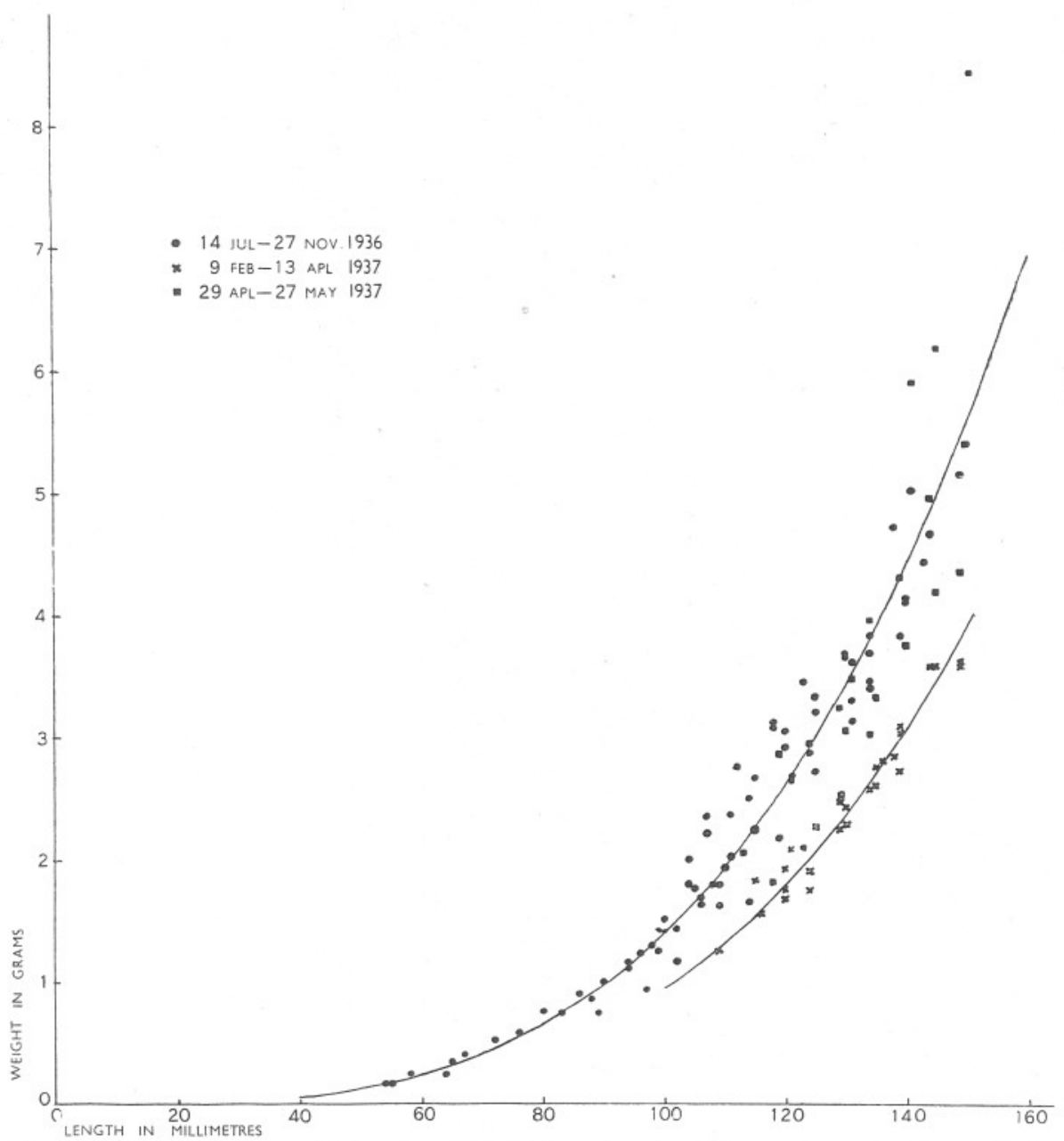

Fig. 5. The relation of weight to length in inshore herring. Upper curve, growing periods; lower curve, non-growing period.

are on or near the lower curve while those of the larger herring approach the upper curve. Thus the larger herring reach summer conditions in advance of the smaller herring.

It will be noticed that the growth period according to weight seems to continue for longer than the growth period according to length and that 
increase in weight begins again in spring before any increase in average length. As will be shown later, this is related to fat storage.

Only a small number of weighings of offshore (Clyde spring-spawned) herring were made and the weight-length relationship found is only slightly

\section{Table IV. Length, Wet-Weight and Dry-Weight Measurements}

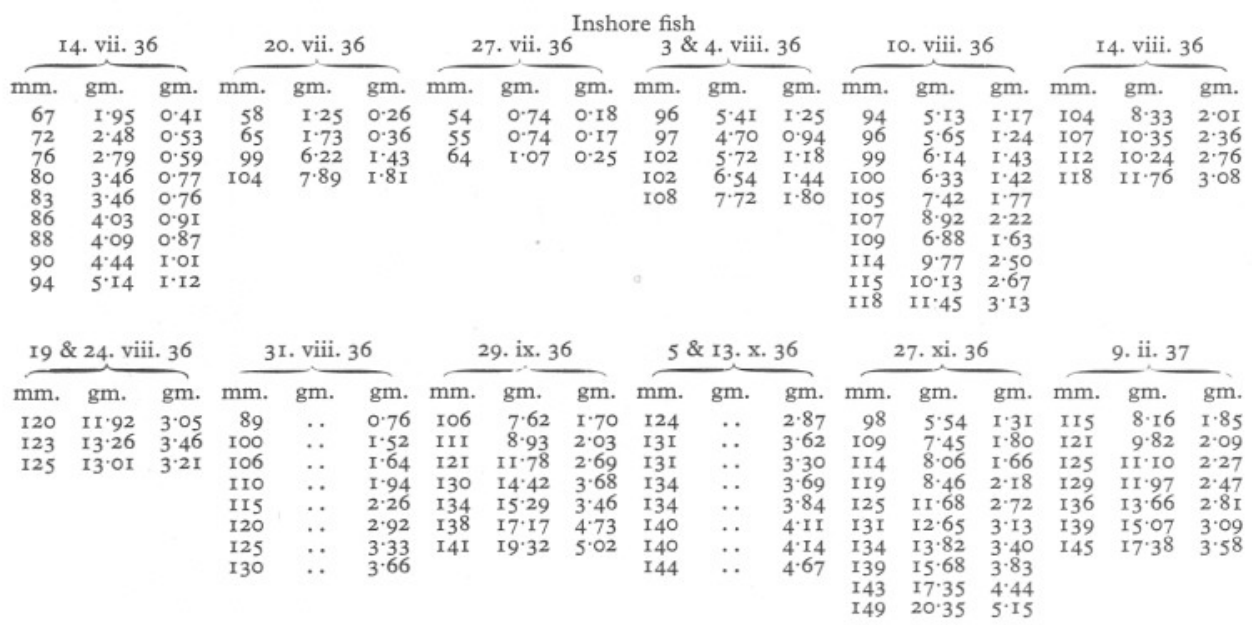

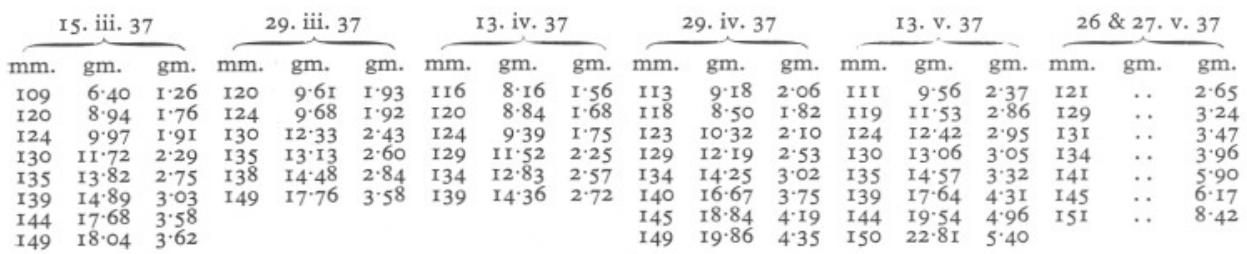

\begin{tabular}{|c|c|c|}
\hline \multicolumn{3}{|c|}{ ro. viii. 36} \\
\hline $\mathrm{mm}$. & $\mathrm{gm}$. & $\mathrm{gm}$. \\
\hline II9 & I0.93 & $2 \cdot 76$ \\
\hline 122 & 10.87 & 2.64 \\
\hline I 24 & 13.06 & 3.49 \\
\hline 125 & 12.42 & 3.09 \\
\hline 129 & I $4: 73$ & $4 \cdot 16$ \\
\hline 131 & 14.95 & 3.80 \\
\hline I 33 & 14.66 & 3.70 \\
\hline I39 & 16.89 & $4 \cdot 28$ \\
\hline I 40 & I 8.34 & $4 \cdot 8 \mathrm{I}$ \\
\hline I 44 & 18.57 & $4 \cdot 78$ \\
\hline 145 & $2 \mathrm{r} \cdot 36$ & 6.25 \\
\hline
\end{tabular}

\begin{tabular}{|c|c|c|c|c|c|}
\hline & $\begin{array}{l}\text { Ishore } \\
26 . \text { v. }\end{array}$ & & & I. iii. 3 & \\
\hline $\mathrm{mm}$. & $\mathrm{gm}$. & $\mathrm{gm}$. & $\mathrm{mm}$. & $\mathrm{gm}$. & $\mathrm{gm}$. \\
\hline I55 & $\cdots$ & $7 \cdot 26$ & 73 & I. 85 & 0.33 \\
\hline 160 & $\ldots$ & 7.40 & 80 & 2.26 & 0.47 \\
\hline 164 & $\ldots$ & 9.51 & 85 & 2.62 & 0.52 \\
\hline 170 & $\cdots$ & IO. 24 & 90 & 3.15 & 0.65 \\
\hline 175 & $\ldots$ & $\mathrm{II} \cdot 76$ & 95 & 4.09 & 0.86 \\
\hline $\mathrm{I} 8 \mathrm{I}$ & $\ldots$ & $12 \cdot 31$ & 100 & 4.77 & 0.99 \\
\hline 185 & $\ldots$ & 13.17 & I05 & 5.66 & I. I 5 \\
\hline 190 & $\ldots$ & I5.66 & Iro & 6.92 & I. 46 \\
\hline & & & II 5 & $7 \cdot 47$ & 1.60 \\
\hline & & & 119 & $9 . \mathrm{II}$ & I. 94 \\
\hline & & & 126 & 10.24 & $2 \cdot 32$ \\
\hline
\end{tabular}

different from that for inshore fish (Table IV and Fig. 7). For the growing period the relationship is given by $W=0.0000000436 L^{3.75}$ but for the winter non-growing period the values were lower and the equation is $W=0.0000000172 L^{3.88}$. The offshore fish in the premetamorphosis stage had a weight-length relationship of $W=0.0000020 L^{4.52}$ (Marshall, Nicholls and Orr, 1937). 


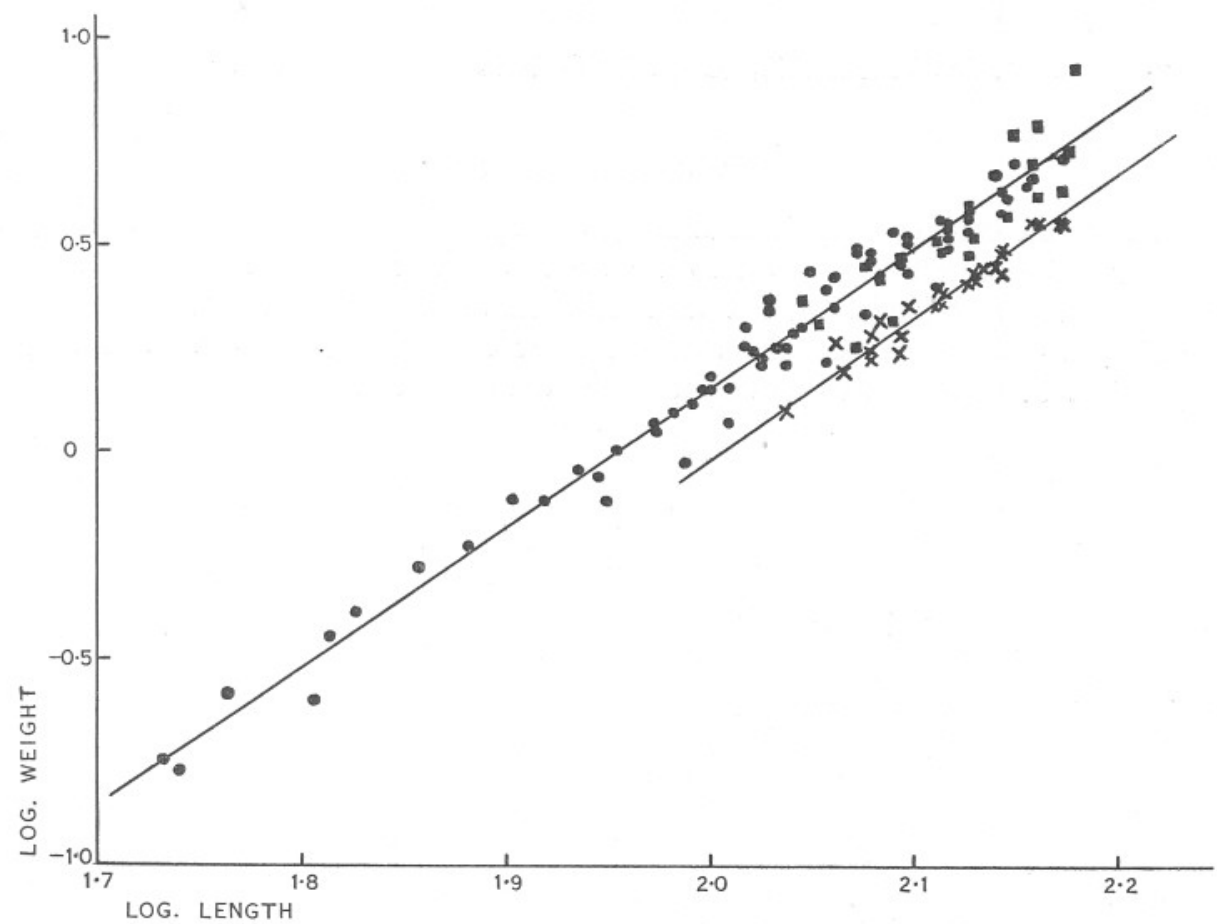

Fig. 6. Relation of logarithm of weight to logarithm of length in inshore herring. Upper curve, growing periods; lower curve, non-growing period. The points are the same as in Fig. 5.

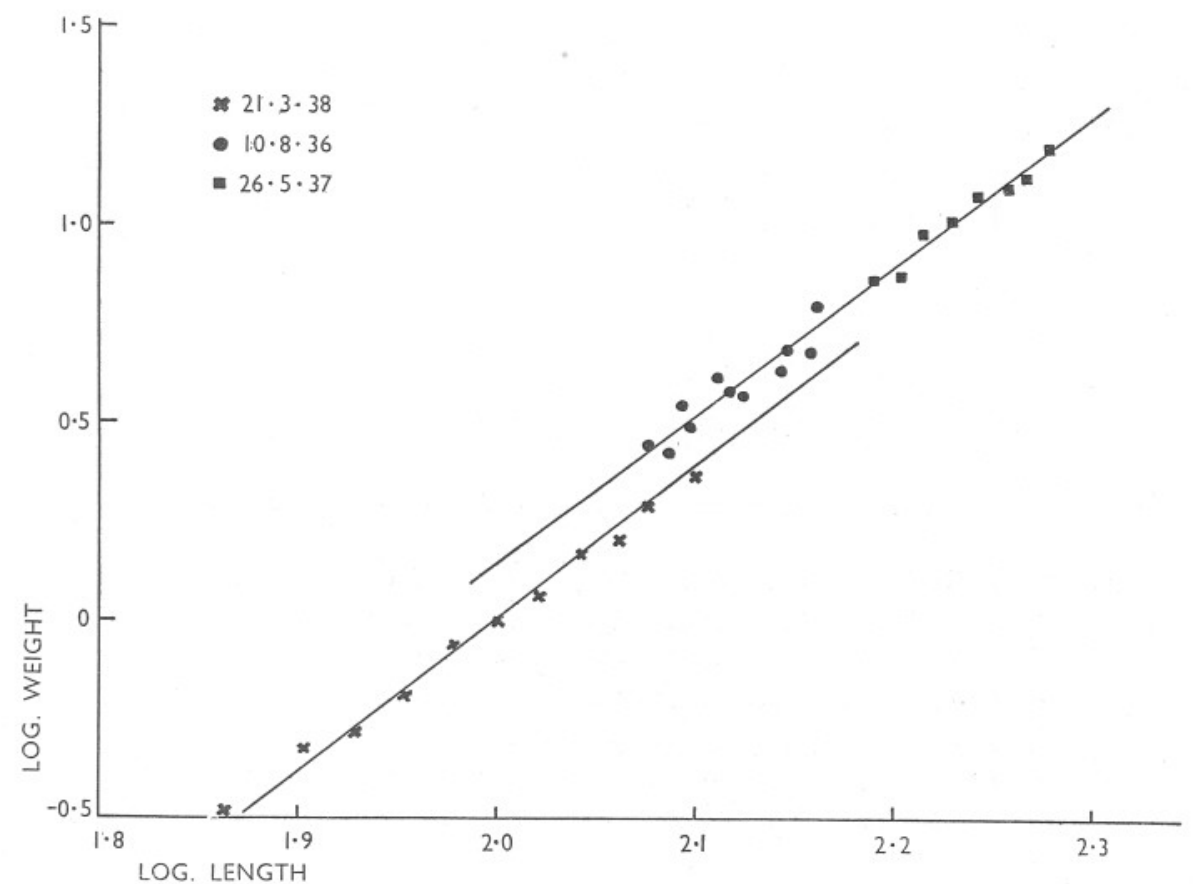

Fig. 7. The relation of logarithm of weight to logarithm of length in offshore herring. Upper curve, growing period; lower curve, non-growing period. 


\section{Chemical Composition}

From the catches of inshore herring a sample of fish of about the average size for the catch was dried to constant weight at $105^{\circ} \mathrm{C}$. and used for determination of protein, fat and ash. Protein was determined by the Kjeldahl method, fat by the Soxhlet ether extraction method and ash by ignition. The results are shown in Table V and Fig. 8.

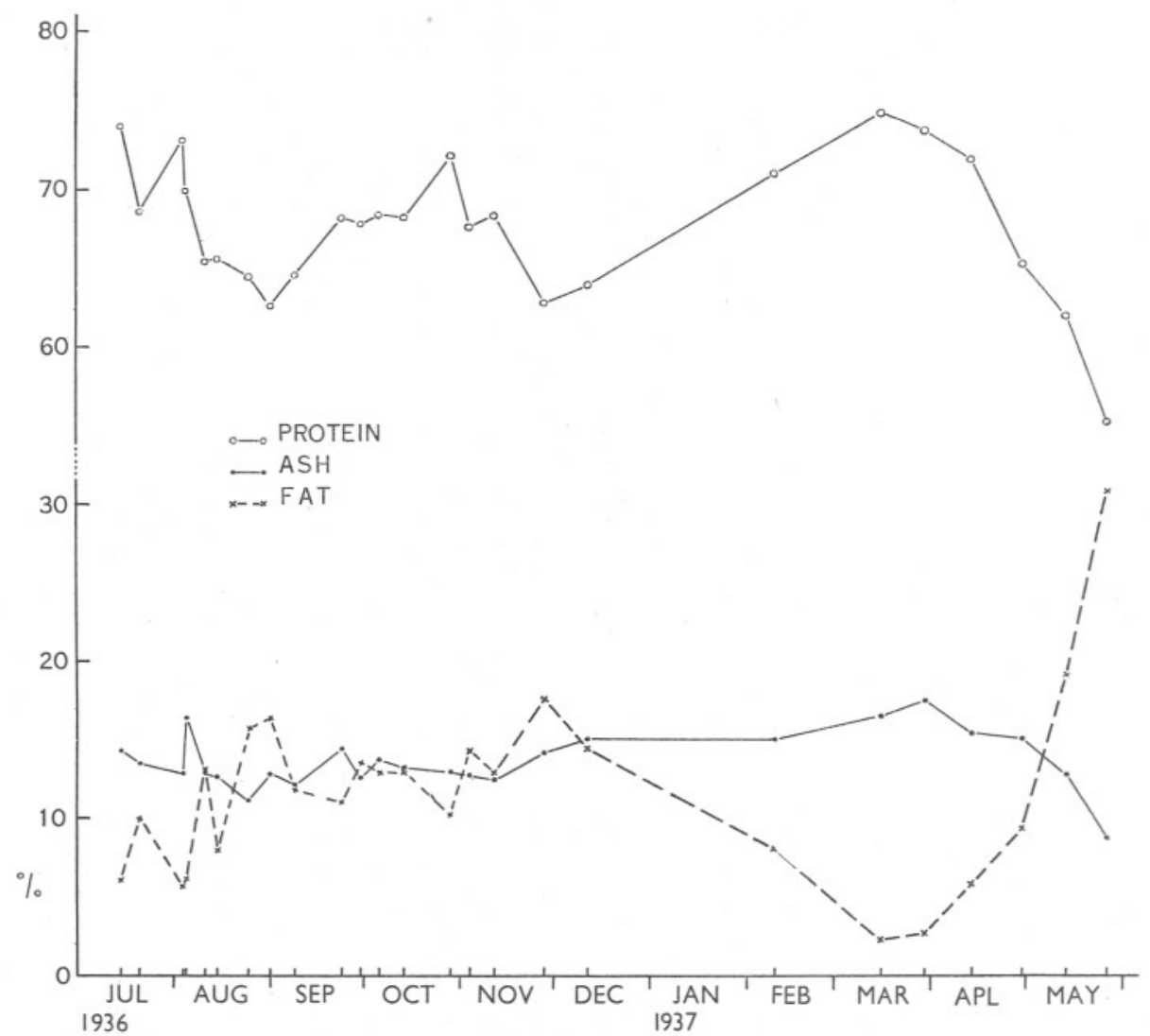

Fig. 8. Percentage chemical composition of inshore herring.

The fat content varied from 2 to $30 \%$. During the growing period it was irregular with a tendency to increase up till the end of November when it was about $17 \%$. This is at least 4 weeks after growth in length had ceased, which suggests that fat was being stored for utilization during the winter. Similarly although fat was increasing from the middle of March onwards, showing that the fish were recuperating, there was no increase in length until May. During the winter only a few analyses were made. By February the fat 
content had fallen considerably and its lowest value was reached on March I5 when it was about $2 \%$. Thereafter there was a steady and rapid increase up to $30 \%$ at the end of May.

The minor irregularities in the fat results may be due to some extent to the size of the fish used in the sample. On August Io 1936, when the size range was considerable, analyses were made on fish of different size ranges. The results (Table V) show that the fat percentage increased with increasing size of fish.

\section{Table V. Chemical Composition}

\begin{tabular}{|c|c|c|c|c|}
\hline \multirow[b]{2}{*}{ Date } & \multirow{2}{*}{$\begin{array}{l}\text { Size } \\
\mathrm{mm} \text {. }\end{array}$} & \multicolumn{3}{|c|}{ Dry weight } \\
\hline & & Protein \% & Fat $\%$ & Ash \% \\
\hline I4. vii. 36 & $80-90$ & 74.01 & $6 \cdot 15$ & $\mathrm{I} 4 \cdot 33$ \\
\hline 20. vii. 36 & $90-100$ & $68 \cdot 56$ & 9.94 & 13.52 \\
\hline 3. viii. 36 & 90-IOO & $73 \cdot 13$ & 5.69 & $12 \cdot 80$ \\
\hline 4. viii. 36 & $90-100$ & $69 \cdot 88$ & $6 \cdot 15$ & I6.38 \\
\hline Io. viii. 36 & IOO-I IO & $65 \cdot 35$ & $13 \cdot 16$ & I2.76 \\
\hline Io. viii. 36 & I IO-I 20 & $61 \cdot 70$ & $16 \cdot 72$ & I2.98 \\
\hline *Io. viii. 36 & $120-130$ & $60 \cdot 30$ & $2 \mathrm{I} \cdot \mathrm{I} 7$ & I2.04 \\
\hline * I0. viii. 36 & $130-140$ & $57 \cdot 37$ & $25 \cdot 42$ & I2.65 \\
\hline I4. viii. 36 & IOO-I IO & 65.57 & $7 \cdot 90$ & $12 \cdot 63$ \\
\hline 24. viii. 36 & .. & $64 \cdot 52$ & 15.71 & II 13 \\
\hline 3 I. viii. 36 & $120-130$ & $62 \cdot 62$ & $16.4 \mathrm{I}$ & $12 \cdot 83$ \\
\hline 8. ix. 36 & $120-130$ & $64 \cdot 57$ & II $\cdot 8 I$ & $\mathrm{I} 2 \cdot \mathrm{I} 2$ \\
\hline 23. ix. 36 & $120-130$ & $68 \cdot 18$ & II·O4 & 14.43 \\
\hline 29. ix. 36 & I35-I40 & $67 \cdot 82$ & 13.55 & $12.5 \mathrm{I}$ \\
\hline $5 . x .36$ & $130-140$ & $68 \cdot 37$ & I 2.89 & 13.70 \\
\hline I3. x. 36 & $130-140$ & $68 \cdot 21$ & I $2 \cdot 88$ & I3. 6 \\
\hline $28 . x \cdot 36$ & I30-I40 & 72.06 & IO. I8 & 12.90 \\
\hline 3. xi. 36 & I30-I40 & 67.61 & 14.35 & I $2 \cdot 7 \mathrm{I}$ \\
\hline II.xi. 36 & $120-130$ & $68 \cdot 26$ & 12.88 & I2.39 \\
\hline 27. xi. 36 & $130-140$ & $62 \cdot 82$ & $17 \cdot 6 \mathrm{I}$ & $\mathrm{I}_{4} \cdot \mathrm{I} 3$ \\
\hline II. xii. 36 & $130-140$ & 63.92 & I $4 \cdot 48$ & I4.99 \\
\hline 9. ii. 37 & $130-140$ & $70 \cdot 98$ & $8 \cdot 10$ & 15.03 \\
\hline I5. iii. 37 & $130-140$ & $74 \cdot 85$ & $2 \cdot 36$ & I6.48 \\
\hline 29. iii. 37 & I30-I40 & $73 \cdot 78$ & $2 \cdot 75$ & I7 49 \\
\hline I3. iv. 37 & I30-I40 & $7 I \cdot 98$ & $5 \cdot 86$ & 15.40 \\
\hline 29. iv. 37 & I30-I40 & $65 \cdot 40$ & $9 \cdot 38$ & $15 \cdot 13$ \\
\hline I3. v. 37 & I35-I45 & $62 \cdot 04$ & $19 \cdot 22$ & 12.77 \\
\hline 26. v. 37 & $160-170$ & $55 \cdot 32$ & 30.90 & $8 \cdot 82$ \\
\hline
\end{tabular}

The protein content varied from 55 to $74 \%$ and its fluctuations correspond inversely to those of the fat content. As has been mentioned above, the fall in fat content in winter is accompanied by an increase in water content so that the wet weight and weight of protein change comparatively little.

In Table VI and Fig. 9 are shown the calculated weight and composition of the average inshore herring during its first year. The lengths and weights were obtained from the curves in Figs. 3 and 5 with interpolations for the change from summer to winter composition. The chemical composition was calculated from the results given in Table $\mathrm{V}$.

The analyses of the chemical composition of the inshore herring show much the same type of seasonal fluctuation as has been found for herring 
muscle by Bruce (1924), Channon \& el Saby (1932), and by Lovern \& Wood (1937). The last authors found a minimum fat content in April of about $2-3 \%$ which is the same as that of the inshore fish in March. This low value is found at the end of the winter period of poor plankton. The maximum value found for fat by Lovern \& Wood (over $20 \%$ ) is lower than the maximum found in inshore fish $(3 \mathrm{I} \%)$, but agrees in that it occurred at the time when food was abundant both in the plankton (spring) and in the herring guts

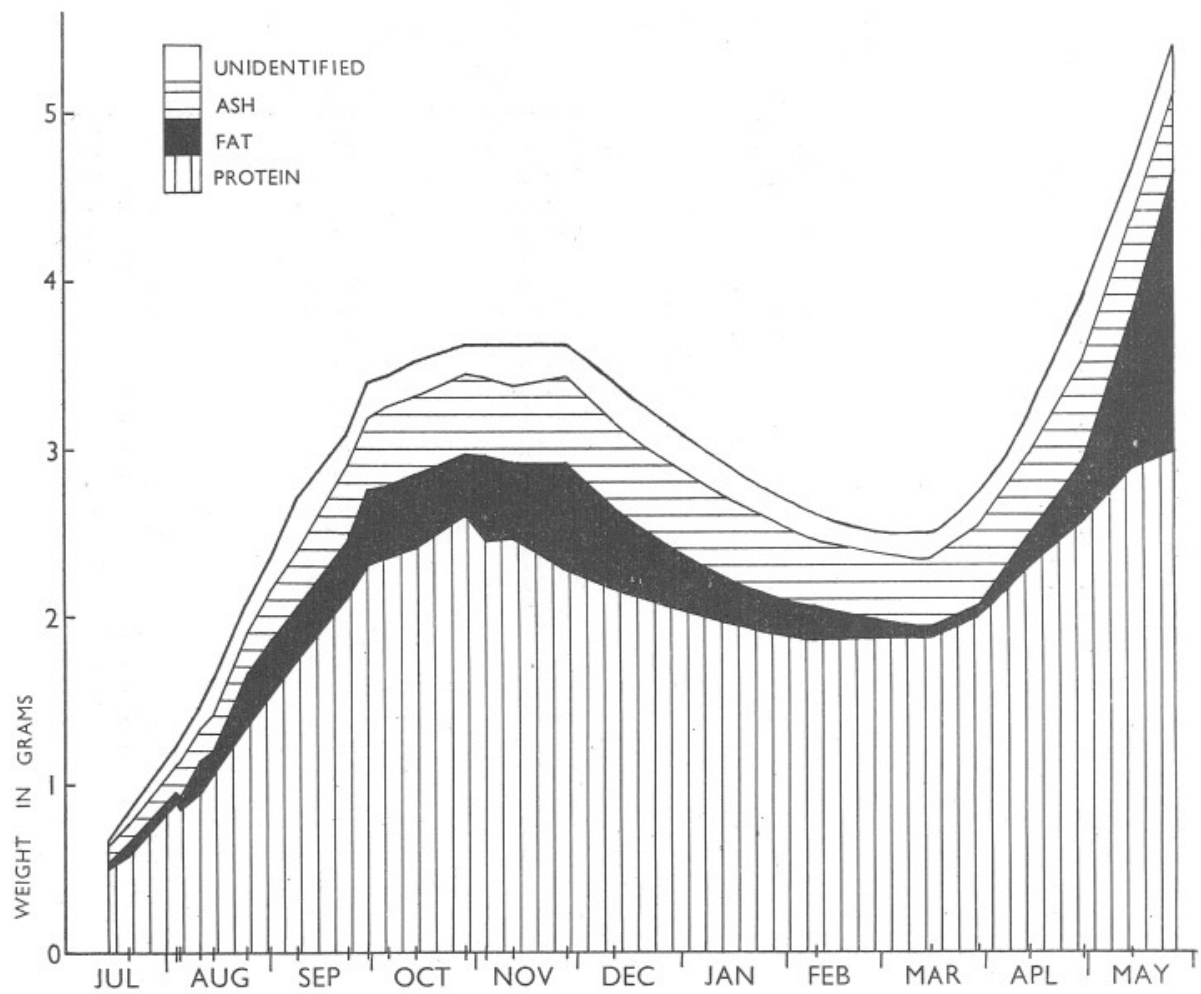

Fig. 9. Dry weight and chemical composition of the average inshore herring.

(Table VII and Fig. Io). Similarly for spring-spawning herring, Lovern \& Wood found values generally high during the summer with a slight additional rise in the late autumn (maximum in December). The fat values for inshore fish remained high during the summer and did not fall till December or later. A close comparison of the results obtained on the young Clyde fish (inshore type) with those of other workers is not possible for two reasons; firstly, in the fish analysed in the present report the whole fish was used and not either the muscle or separate organs; secondly, the influence of the state of sexual maturity on the fat content of different tissues of adult herring is important. 
It would have been desirable to remove the gut contents before analysis, but this omission is likely to have had only a very small effect. In the most striking case where food was abundant and consisted chiefly of Calanus, it is possible to calculate the effect of the inclusion of the gut contents. Each fish

\section{Table VI. Composition of Average Herring}

\begin{tabular}{|c|c|c|c|c|c|}
\hline Date & $\begin{array}{l}\text { Av. length } \\
\text { mm. }\end{array}$ & $\begin{array}{l}\text { Av. wt. } \\
\text { gm. }\end{array}$ & $\begin{array}{l}\text { Protein } \\
\text { gm. }\end{array}$ & $\begin{array}{l}\text { Fat } \\
\text { gm. }\end{array}$ & $\begin{array}{l}\text { Ash } \\
\text { gm. }\end{array}$ \\
\hline I4. vii. 36 & 80 & 0.67 & 0.50 & 0.04 & 0.10 \\
\hline 20. vii. 36 & 86 & 0.85 & 0.58 & 0.08 & O.II \\
\hline 3. viii. 36 & 96 & $I \cdot 22$ & 0.89 & 0.07 & 0.16 \\
\hline 4. viii. 36 & 96 & $I \cdot 22$ & 0.85 & 0.08 & 0.20 \\
\hline Io. viii. 36 & IOI & $I \cdot 46$ & 0.95 & 0.19 & 0.19 \\
\hline I4. viii. 36 & IO4 & $I \cdot 63$ & I.07 & 0.13 & 0.21 \\
\hline 24. viii. 36 & II 2 & 2.07 & $I \cdot 34$ & 0.32 & 0.23 \\
\hline 3 I. viii. 36 & II 6 & $2 \cdot 35$ & $I \cdot 47$ & 0.39 & 0.30 \\
\hline 8. ix. 36 & I2I & $2 \cdot 70$ & $I \cdot 74$ & 0.32 & 0.33 \\
\hline 23. ix. 36 & I 26 & 3.09 & $2 \cdot \mathrm{II}$ & 0.34 & 0.45 \\
\hline 29. ix. 36 & I29 & $3 \cdot 39$ & $2 \cdot 30$ & 0.46 & 0.42 \\
\hline $5 \cdot x \cdot 36$ & I30 & 3.43 & $2 \cdot 34$ & 0.44 & 0.47 \\
\hline I3. x. 36 & I3I & 3.52 & $2 \cdot 40$ & 0.45 & 0.46 \\
\hline $28 . x .36$ & I32 & 3.61 & $2 \cdot 60$ & 0.37 & 0.47 \\
\hline 3. xi. 36 & 132 & $3 \cdot 6 \mathrm{I}$ & $2 \cdot 44$ & 0.52 & 0.46 \\
\hline I I. xi. 36 & I32 & $3 \cdot 6 \mathrm{I}$ & $2 \cdot 46$ & 0.46 & 0.45 \\
\hline 27. xi. 36 & I32 & $3 \cdot 61$ & $2 \cdot 27$ & 0.64 & $0.5 \mathrm{I}$ \\
\hline I I. xii. 36 & 132 & $(3 \cdot 38)$ & $2 \cdot 16$ & 0.49 & 0.51 \\
\hline 9. ii. 37 & I32 & $(2 \cdot 60)$ & $I \cdot 85$ & $0.2 \mathrm{I}$ & 0.39 \\
\hline I5. iii. 37 & 132 & 2.50 & I. 87 & 0.06 & $0.4 \mathrm{I}$ \\
\hline 29. iii. 37 & 132 & $(2 \cdot 70)$ & $I \cdot 99$ & 0.07 & 0.47 \\
\hline I3. iv. 37 & I32 & $(3 \cdot 18)$ & $2 \cdot 29$ & 0.19 & 0.49 \\
\hline 29. iv. 37 & I35 & 3.91 & $2 \cdot 56$ & 0.37 & 0.59 \\
\hline I3. v. 37 & I 42 & $4 \cdot 63$ & $2 \cdot 87$ & 0.89 & 0.59 \\
\hline 26. v. 37 & I56 & $5 \cdot 38$ & $2 \cdot 98$ & $I \cdot 66$ & 0.47 \\
\hline
\end{tabular}

on May 26 I937 contained on an average almost 2000 Calanus and since the composition of Calanus is known (Marshall, Nicholls \& Orr, I934) it can be calculated that the gut contents accounted for about $0.06 \mathrm{gm}$. fat, i.e. only about I \% of the fat in the fish is represented by the Calanus in the gut. At other times the food in the gut is negligible from this aspect.

\section{Food and its Relation to the Plankton}

When a catch of herring was taken, a number of fish was immediately preserved in formalin for food examination. From ten of these the guts were removed, opened, and the contents mixed. The volume of this was measured after settlement and a subsample was then examined and all recognizable organisms counted. When the fish were small or the guts nearly empty, a larger number was used, but the results are always expressed as the number of organisms per fish. They are shown in Table VII and Fig. Io. The numbers of herring used are of course too small for accurate quantitative work, but the results give a good indication of the type of food being eaten. 


\section{TABLE VII. FoOd OF INSHORE HERRING}

\begin{tabular}{|c|c|c|c|c|c|c|c|c|c|c|c|c|c|c|c|c|c|c|}
\hline \multirow[b]{2}{*}{ Date } & \multirow{2}{*}{$\begin{array}{l}\text { Volume } \\
\text { c.c. }\end{array}$} & \multicolumn{2}{|c|}{ Calamus } & \multicolumn{2}{|c|}{$\begin{array}{c}\text { Harpacticoid } \\
\text { copepods }\end{array}$} & \multicolumn{2}{|c|}{$\begin{array}{l}\text { Other } \\
\text { copepods }\end{array}$} & \multicolumn{2}{|c|}{ Cladocera } & \multicolumn{2}{|c|}{$\begin{array}{l}\text { Ostracods and } \\
\text { cirripedes }\end{array}$} & \multicolumn{2}{|c|}{ Cyphonautes } & \multicolumn{2}{|c|}{$\begin{array}{c}\text { Molluscan } \\
\text { larvae }\end{array}$} & \multirow{2}{*}{$\begin{array}{c}\text { Other } \\
\text { organ- } \\
\text { isms }\end{array}$} & \multirow{2}{*}{$\begin{array}{l}\text { Total } \\
\text { no. }\end{array}$} & \multirow[b]{2}{*}{ Notes } \\
\hline & & $\overparen{\text { No. }}$ & $\%$ & No. & $\%$ & No. & $\%$ & No. & $\%$ & No. & $\%$ & No. & $\%$ & No. & $\%$ & & & \\
\hline 14. vii. 36 & & & & 2452 & $90 \cdot 4$ & 238 & 9.0 & 2 & $O \cdot I$ & 5 & 0.2 & & & I & 0.1 & 13 & $27 \mathrm{II}$ & 3 amphipods \\
\hline 20. vii. 36 & 0.5 & 146 & I5. I & 74 & $7 \cdot 6$ & 459 & $47 \cdot 5$ & 246 & $25 \cdot 4$ & 9 & 0.9 & $\ddot{2}_{2}$ & $\ddot{0} 2$ & 22 & $2 \cdot 3$ & II & 967 & 3 ämipingor \\
\hline 27. vii. 36 & 0.4 & $\therefore$ & .. & $7 \mathrm{I}$ & $13 \cdot 2$ & 213 & 39.4 & 102 & $\mathrm{I} 8 \cdot 9$ & 8 & I. 5 & 64 & II $\cdot 9$ & 70 & 13.0 & 12 & 540 & $\therefore$ \\
\hline 3. viii. 36 & 0.7 & 4 & 0.2 & 9 & 0.5 & 988 & 56.8 & 699 & $40 \cdot 2$ & 13 & 0.7 & 9 & 0.5 & 14 & 0.8 & 2 & 1738 & $, \quad, \quad$, \\
\hline Io. viii. 36 & $1 \cdot 3$ & 453 & $31 \cdot 6$ & 3 & 0.2 & 504 & $35 \cdot 2$ & 413 & $28 \cdot \overline{8}$ & 6 & 0.4 & 20 & $\mathrm{I} \cdot 4$ & 13 & 0.9 & 23 & I434 & I2 polychaete larvae \\
\hline 14. viii. 36 & 0.5 & 8 & I.7 & 146 & $30 \cdot 2$ & 99 & 20.4 & 54 & II $\cdot 2$ & 34 & 7.0 & 117 & $24 \cdot 2$ & 19 & 3.9 & 7 & 484 & . \\
\hline 24. viii. 36 & 0.6 & I & $0 \cdot 1$ & 9 & 0.5 & 176 & $9 \cdot 4$ & 6 & 0.3 & 22 & $1 \cdot 2$ & 1643 & $88 \cdot 2$ & 7 & 0.4 & $\therefore$ & $\begin{array}{l}1864 \\
4\end{array}$ & $\therefore$ \\
\hline 31. viii. 36 & 1.05 & $\mathrm{I}$ & 0.3 & 3 & 1.0 & 207 & 69.0 & II & 3.7 & 4 & $\mathrm{I} \cdot 3$ & 64 & $2 \mathrm{I} \cdot 3$ & I & 0.3 & 8 & 300 & $\because$. \\
\hline 8. ix. 36 & 0.9 & I & 0.1 & 7 & 0.9 & 592 & $73 \cdot 6$ & 9 & $\mathbf{I} \cdot \mathbf{I}$ & 5 & 0.6 & $\begin{aligned} 114 \\
\mathrm{II}\end{aligned}$ & $14 \cdot 2$ & 15 & I. 9 & $6 \mathrm{I}$ & 804 & 6I polychaete larvae \\
\hline I5. ix. 36 & 0.7 & & $\therefore$ & 2 & 0.1 & 165 & $5 \cdot 3$ & II & 0.4 & 12 & 0.4 & 2896 & $93 \cdot 2$ & 19 & 0.6 & 4 & 3109 & . \\
\hline${ }^{\star} 21$. ix. 36 & $r \cdot 3$ & 635 & $65 \cdot 3$ & .. & . & 310 & $3 \mathrm{I} \cdot 9$ & . & .. & .. & .. & .. & & $\cdots$ & $\cdots$ & 30 & 973 & 24 Oikopleura \\
\hline 23. ix. 36 & 0.55 & $\cdots$ & .. & 3 & 0.7 & 405 & $94 \cdot 2$ & 6 & I. 4 & I & 0.2 & 9 & $2 \cdot 1$ & $\mathrm{I}$ & $0 \cdot 2$ & 5 & 430 & 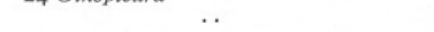 \\
\hline 29. ix. 36 & 0.55 & .. & & 9 & $2 \cdot 7$ & 317 & 95.5 & I & 0.3 & .. & .. & .. & .. & .. & .. & 5 & 332 & .. \\
\hline 5. x. 36 & 0.7 & 27 & 6.6 & I & $0 \cdot 2$ & 324 & 79.9 & 2 & 0.5 & 2 & $\ddot{0} 5$ & $\ddot{47}$ & $\ddot{I I} \cdot 6$ & 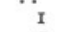 & $\ddot{0} 2$ & 2 & 406 & $\therefore$ \\
\hline 13.x. 36 & $I \cdot I$ & 435 & $39 \cdot 6$ & .. & .. & 467 & $42 \cdot 6$ & 18 & 1.6 & 6 & 0.5 & $\begin{array}{r}41 \\
3\end{array}$ & 0.3 & I & 0.1 & I68 & 1097 & 2 Zoeae; 3 Megalopa; 2 mysids; \\
\hline 28. x. 36 & $0 \cdot 8$ & 12 & 2.5 & 2 & 0.4 & 405 & $89 \cdot 4$ & 5 & $I \cdot I$ & $\cdots$ & & 8 & $\mathrm{r} \cdot 8$ & I & 0.2 & 20 & 453 & 4 amphipods; 5 Zoeae \\
\hline 3. xi. 36 & 0.6 & 46 & $35 \cdot 7$ & 4 & $3 \cdot \mathrm{T}$ & 73 & 56.6 & $\ldots$ & $\cdots$ & I & 0.8 & I & 0.8 & 2 & $\mathrm{x} \cdot \overline{6}$ & 2 & 129 & \\
\hline 13. xi. 36 & $\mathrm{r} \cdot 8$ & 575 & $74 \cdot 3$ & . & .. & 194 & $25 \cdot 1$ & .. & . & .. & $\cdots$ & $\ldots$ & . & . & $\therefore$ & 5 & 774 & I euphausid; Sagitta present \\
\hline $27 . x i \cdot 36$ & 0.45 & 22 & $38 \cdot 6$ & 2 & 3.5 & 32 & $56 \cdot \mathrm{I}$ & . & . & . & . & . & . & $\therefore$ & $\therefore$ & I & 57 & - \\
\hline II. xii. 36 & 0.2 & I & 3.7 &. & $\because$ & 24 & $88 \cdot 9$ & . & .. & . & .. & $\cdots$ & $\cdots$ & . & .. & 3 & 27 & $=0$. \\
\hline 28. xii. 36 & 0.25 & I & 2.6 & I & $2 \cdot 6$ & 35 & $92 \cdot 2$ & .. & . & . & .. & .. & .. & .. & .. & $\mathbf{I}$ & 38 & I Sagitta \\
\hline 13. i. 37 & 0.6 & 28 & $49 \cdot \mathrm{I}$ & .. & .. & 16 & $28 \cdot I$ & . & .. & . & . & .. & . & . & .. & 13 & 57 & II Sagitta; I amphipod \\
\hline 9. ii. 37 & 0.8 & 66 & 80.5 & 2 & $2 \cdot 4$ & 9 & II $* 0$ & . & .. & . & . & .. & . & .. & . & 4 & 82 & Remains of fish larva; Sagitta present \\
\hline †I. iii. 37 & 0.6 & 40 & $57 \cdot \mathrm{I}$ & I & $\mathrm{I} \cdot 4$ & 9 & $12 \cdot 9$ & $\cdots$ & . & $\cdots$ & $\cdots$ & $\cdots$ & $\cdots$ & .. & $\cdots$ & 18 & 70 & 4 amphipods; Io Cumacea; I mysid; \\
\hline I5. iii. 37 & 0.45 & 12 & $27 \cdot 9$ & 5 & II 6 & 12 & 27.9 & . & .. & $\cdots$ & . & . & $\therefore$ & . & . & 13 & 43 & 8 amphipods; 5 Cumacea; remains of \\
\hline 29. iii. 37 & 0.5 & I & 0.8 & 20 & 15.9 & II & $8 \cdot 7$ & . & . & $83 \ddagger$ & 65.9 & .. & .. & .. & .. & II & 126 & $¥$ All cirripede nauplii \\
\hline 13. iv. 37 & 0.8 & 60 & $10 \cdot 0$ & 6 & I. & 94 & 15.7 & .. & .. & $426 \neq$ & $7 \mathrm{I} \cdot \mathbf{2}$ & . & . & I & $0 \cdot 2$ & I0 & 598 & $\neq 215$ cirripede nauplii; 2 II cyprids \\
\hline 29. iv. 37 & 0.9 & 5 & 0.4 & 8 & 0.6 & $2 \mathrm{I}$ & 1.6 & .. & .. & $1286 \neq$ & $97 \cdot 4$ & . & . & .. & . & I & $132 \mathrm{I}$ & $\mp 104$ cirripede nauplii; 1182 cyprids \\
\hline 13. v. 37 & $1 \cdot 3$ & 317 & $67 \cdot 4$ & 3 & 0.6 & 124 & $26 \cdot 4$ & 4 & 0.9 & I4 & 3.0 & .. & .. & .. & . & 8 & 470 & .. \\
\hline †26. v. 37 & 3.75 & 1856 & 92.0 & 9 & 0.4 & 132 & 6.6 & II & 0.5 & 2 & 0.1 & $\because$. & $\because$ & $\because$. & $\because$. & 7 & 2017 & $\because$ \\
\hline 27 . v. 37 & 2.0 & 521 & $61 \cdot 6$ & 49 & $5 \cdot 8$ & $24 \mathrm{I}$ & $28 \cdot 5$ & $2 \mathrm{I}$ & $2 \cdot 5$ & 4 & 0.5 & $\therefore$ & $\therefore$ & $\ldots$ & .. & 9 & 845 & $\because$. \\
\hline 3 I. v. 27 & 0.7 & 26 & $4 \cdot 4$ & 347 & $58 \cdot 2$ & II3 & 19.0 & 75 & 12.6 & 3 & 0.5 & .. & $\because$ & 2 & $0 \cdot 3$ & 30 & 596 & I2 mysids; I2 decapod larvae \\
\hline II. viii. 37 & 0.6 & I & 0.4 & ${ }^{34}$ & 0.2 & 627 & $98 \cdot 8$ & . & . & .. & . & $\therefore$ & $\therefore$ & .. & .. & 4 & 634 & A the tar \\
\hline
\end{tabular}


During the growing period both in summer 1936 and spring 1937 , the gut contents of the inshore fish varied considerably both in volume and composition; in the winter the majority of the guts were almost empty.

For most of the year copepods formed the bulk of the food, but in spring and summer, at times when other organisms were common in the plankton, an individual catch might show these in abundance. Thus during August and September Cyphonautes (polyzoan larvae) were common and on September I5 rose to $93 \%$ of the total numbers. In spite of their large numbers, however,

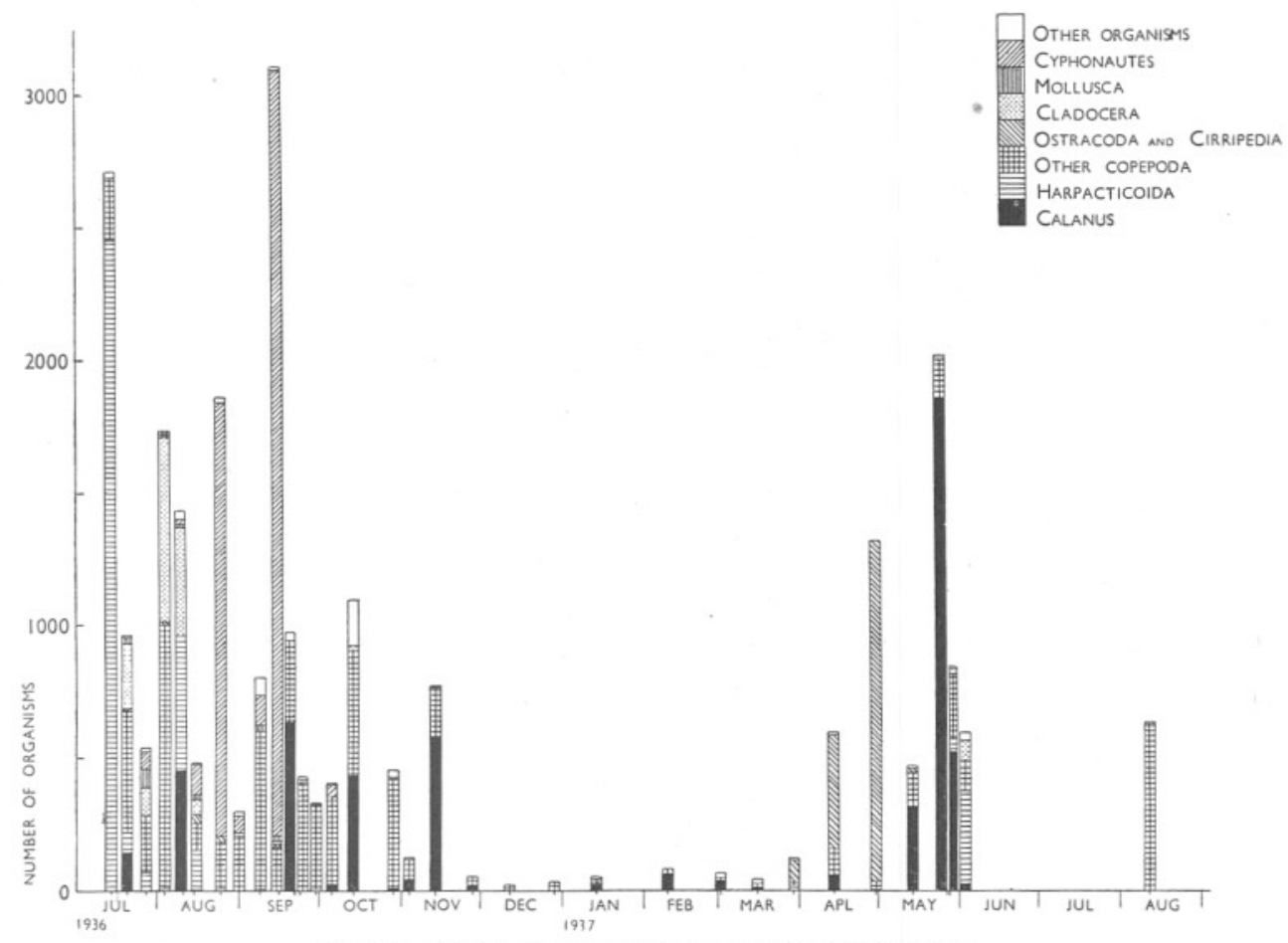

Fig. Io. Composition of the food of inshore herring.

they are relatively unimportant as food because of their small size. On September I5 when 2896 Cyphonautes were present the total volume of the food was only 0.7 c.c. In spring cirripede larvae, both nauplii and cyprids, were abundant and on April 29 formed $97.4 \%$ of the food. Cirripede larvae and Cyphonautes were the most important organisms occurring sporadically, but, as may be seen in Table VII, euphausids, Cladocera, Sagitta, and Oikopleura all appeared at times. Occasionally a few Chironomus larvae were ingested.

Of the copepods Calanus, although not the most numerous, was certainly the most important owing to its large size. In Fig. II which shows the volume 
of the gut contents each of the peaks, with the exception of that on August 3I, is due to the presence of Calanus. In May when the herring were increasing rapidly in weight and fat content, they were feeding mainly on Calanus and on May 26 there were 1856 Calanus per gut. The other copepods were most numerous from July to October, Pseudocalanus, Microcalanus, and Acartia appearing for longer than Centropages, Temora, and Oithona. All disappeared almost completely during the winter to reappear again in May. In July to August 1936 and in May 1937 harpacticoid copepods were common and on one occasion, July I4, each gut contained on the average 2452 , forming $90 \%$ by number of the food organisms. They were mostly littoral forms, e.g. Dactylopusia and other thalestrids, showing that the herring were feeding inshore.

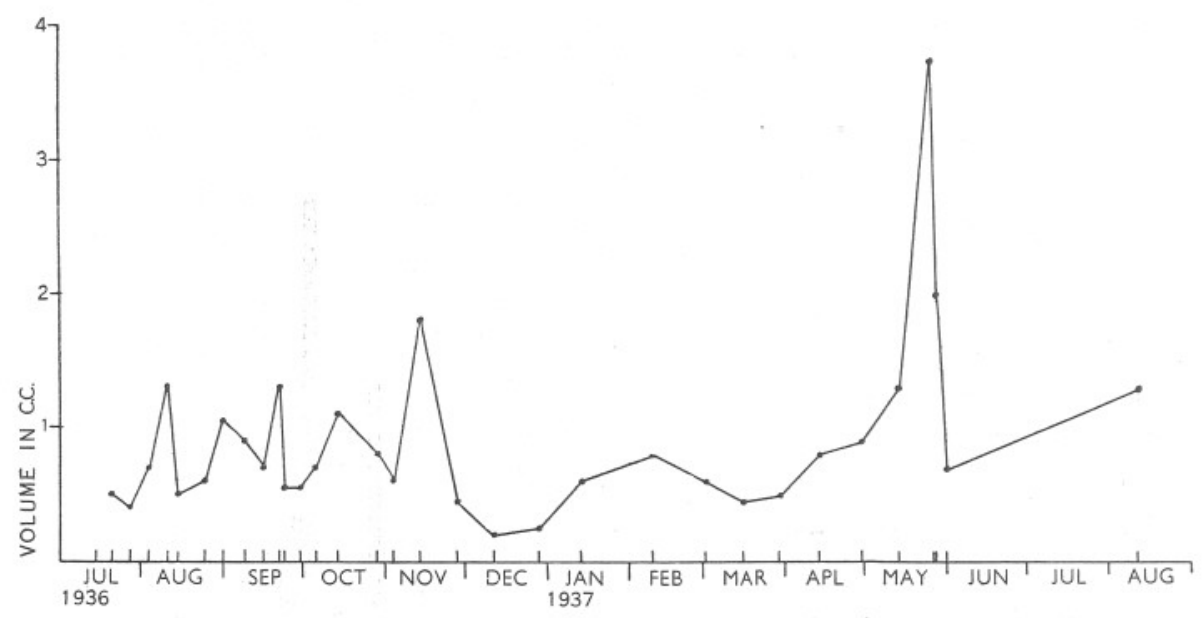

Fig. II. Volume of the food of inshore herring.

On August I4-I5 when herring were caught at $2 \mathrm{hr}$. intervals during the night, a sample of the guts was examined from each catch (Table VIII and Fig. I2). The volume of the food was never large but was highest from 7-II p.m. and lowest from I-5 a.m. Copepods were the most numerous organisms in the catch at $5 \mathrm{p} . \mathrm{m}$. when there were over 1000 harpacticoids per gut. In the catches from 7-II p.m. Centropages, Temora, Cladocera, cirripede larvae, and Cyphonautes formed the bulk of the food, as they did also in the later catches, although very much less numerous. It was hoped to find out if the fish came inshore to feed and at what time during the night they fed most, but from this point of view the results were disappointing. The harpacticoids in the first catch indicate that they had been feeding inshore, but in this, as in all catches, most of the food was in the intestine and little in the stomach which suggests that they were not feeding at the time they were caught. 
A comparison of the volume of the gut contents with the growth curve for the herring and their chemical composition shows general agreement (Figs. II, 3 and 8). When the volume of the food was high during the summer of 1936 and the spring of 1937 , the herring were growing. During the winter period when food was scarce, growth had stopped and the fish were losing fat. Although growth had stopped by the middle of October, the volume of the food was still considerable and it has been shown that it was being used partly for fat storage; similarly the food showed an increase in spring some time before any increase in length began, correlated with the replacement of fat lost in winter.

Only six samples of offshore (Clyde spring-spawned) fish were examined and they showed little difference from the inshore fish in their food except that there was a reduction in the number of harpacticoid copepods.

Table VIII. Food of Herring during Night of August I4-I5 1936

\begin{tabular}{|c|c|c|c|c|c|c|c|c|c|c|c|}
\hline Time & $\begin{array}{l}\text { No. of } \\
\text { herring }\end{array}$ & $\begin{array}{l}\text { Volume } \\
\text { of food } \\
\text { in c.c. }\end{array}$ & $\begin{array}{c}\text { Calanus } \\
\text { no. }\end{array}$ & $\begin{array}{c}\text { Harpac- } \\
\text { ticoid } \\
\text { copepods } \\
\text { no. }\end{array}$ & $\begin{array}{l}\text { Other } \\
\text { copepods } \\
\text { no. }\end{array}$ & $\begin{array}{l}\text { Clado- } \\
\text { cera } \\
\text { no. }\end{array}$ & $\begin{array}{l}\text { Ostracods } \\
\text { and } \\
\text { cirri- } \\
\text { pedes } \\
\text { no. }\end{array}$ & $\begin{array}{c}\text { Cypho- } \\
\text { nautes } \\
\text { no. }\end{array}$ & $\begin{array}{c}\text { Molluscan } \\
\text { larvae } \\
\text { no. }\end{array}$ & $\begin{array}{l}\text { Other } \\
\text { organisms } \\
\text { no. }\end{array}$ & $\begin{array}{c}\text { Total } \\
\text { no. }\end{array}$ \\
\hline 5 p.m. & $I_{32}$ & 0.5 & . & 1063 & 203 & $\mathrm{IO}_{3}$ & I 24 & 438 & 25 & I4 & 1970 \\
\hline 7 p.m. & 4500 & 0.7 & 43 & 9 & 144 & 140 & 53 & 65 & 45 & IO & 509 \\
\hline 9 p.m. & $>10000$ & 0.7 & 4 & 3 & 192 & II 4 & 33 & 30 & 16 & 12 & 404 \\
\hline II p.m. & 450 & 0.7 & 7 & 21 & 97 & 40 & 22 & 340 & IO & 9 & 546 \\
\hline I a.m. & Io & 0.3 & . & 34 & 29 & I4 & 20 & II & I4 & 7 & 129 \\
\hline 3 a.m. & 12 & 0.3 & $\cdots$ & $3 I$ & 45 & 6 & II & 23 & 17 & 5 & I 38 \\
\hline 5 a.m. & 293 & 0.25 & $\ldots$ & I & 8 & I & $\ldots$ & 9 & 4 & $\therefore$ & 23 \\
\hline 7 a.m. & 6 & 0.45 & I3 & 8 & $7 \mathrm{I}$ & I 7 & 5 & 20 & 15 & 5 & I 54 \\
\hline
\end{tabular}

When a catch of herring was made, a tow-netting was taken in the same place. A 5 minute haul was made with a $40 \mathrm{~cm}$. fine silk net at about $\mathrm{I} \mathrm{m}$. below the surface and all organisms counted after preservation in formalin. The results are given in Table IX, in which the organisms are grouped as in Table VII to assist comparison. The figures for August I4 1936 are averages based on all the hauls taken during the night of August I4-I5. The object was to compare the plankton with the food in the herring guts.

As might be expected, the plankton hauls were poor during the winter period and rich during the spring and summer but, apart from this general relationship, the comparison with the contents of the herring guts is disappointing. The reason for the poor agreement between plankton hauls and gut contents is probably that on the majority of occasions the herring had been feeding offshore, whereas the tow-nettings were taken inshore where the herring were actually captured.

The most striking agreement was from March 29 to April 29 when cirripede larvae, first as nauplii and then as cyprids, were abundant both in the townettings and in the food. Oikopleura was common in both on September 2I and October I3. Cladocera were represented seasonally in the guts according to their appearance in the plankton, as was also Cyphonautes. With animals like the last, which occur in swarms, it is largely a matter of chance whether they are richly represented in the catch or not. Although Cyphonautes was 


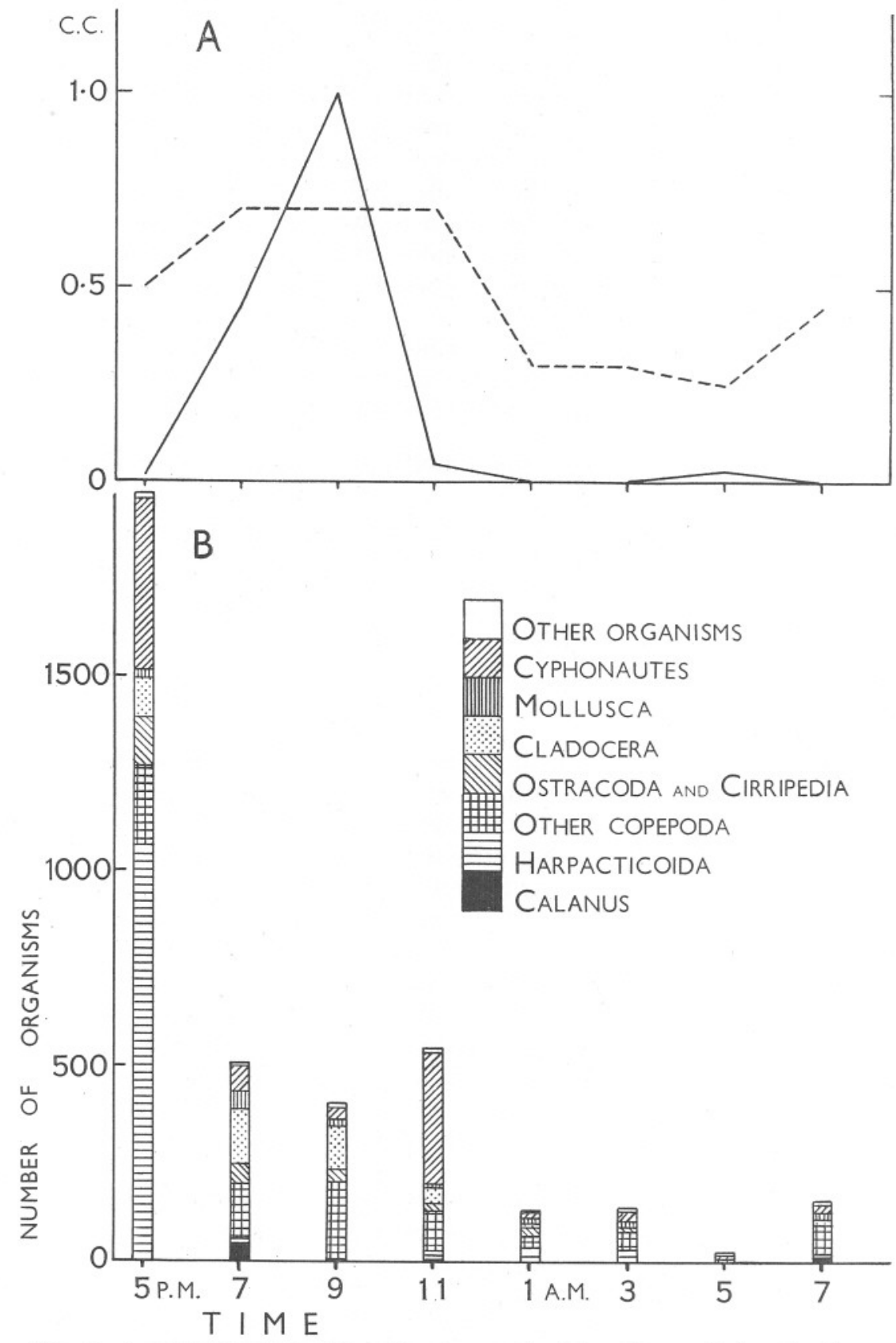

Fig. I2. A, approximate number of herring per haul (continuous line) and volume of food per herring (broken line) from 5 p.m. to 7 a.m. August 14-15 1936. B, composition of the food over the same period. 


\section{Table IX. Plankton}

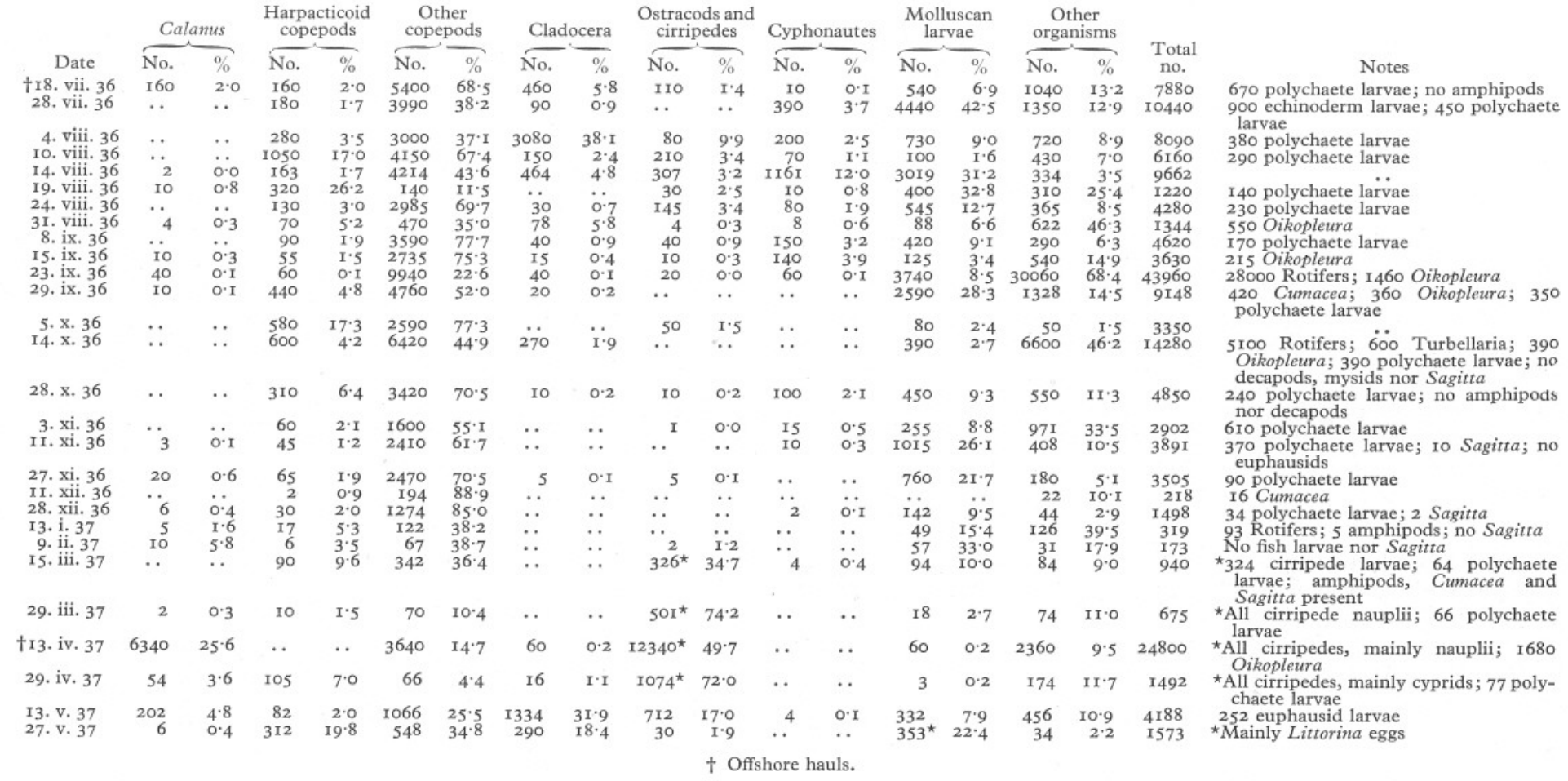


not obtained on the dates they occurred in the herring guts, additional tow-nettings taken in Kames Bay about the same time showed that they were abundant. Among the herring also not all the guts contained Cyphonautes, but in four out of ten the intestine was packed with them.

The most marked disagreement is in the numbers of Calanus, which was frequently common in the guts and quite absent from the plankton hauls. This suggests that the herring had been feeding offshore before they were caught although the presence of typical littoral plankton, e.g. harpacticoids, shows that they fed inshore as well. On only one occasion was Calanus abundant in the tow-nettings and that was when the haul was taken further off shore than usual.

Much has been written on the food of the herring, but it has been mainly concerned with adult fish. In general it is agreed that herring on the west coast of Scotland depend more upon copepods and euphausids than do those on the east coast (Scott, 1907) which have a larger proportion of young fish (mainly Ammodytes) in their diet (Hardy, 1924; Savage, 1937). The food of young herring about $50-150 \mathrm{~mm}$. in length is dealt with in papers by Hardy (1924), Jespersen (1928), Wailes (1936), and Battle et al. (1936).

In general our results are in good agreement with theirs. Copepods form the chief part of the diet and other organisms appear seasonally. Hardy, (1924) dealing with whitebait herring in the Thames estuary, found copepods, chiefly Pseudocalanus, Temora, and Eurytemora common, harpacticoids numerous at times, and cyprid larvae of cirripedes important in spring and autumn. Ogilvie (1934) mentions that harpacticoids, though rare in adult herring, are frequent in young herring. Jespersen's (1928) young herring of 6-I4 cm. were caught only in the winter half-year but they were then feeding voraciously, mainly on copepods (Temora, Pseudocalanus and Paracalanus). $\mathrm{He}$ found that non-crustaceous food was more important for young than for adult fish. Cyphonautes, however, was rarely taken although common in the plankton from February to March, which contrasts with our results. Another contrast is that his herring (adults in this case) appeared to select cirripede cyprids even when the nauplii were more abundant, whereas ours took both in large quantities according to their abundance in the plankton.

Only a few records are available of the fluctuations in the gut contents over the day. Jespersen (1928) compared the quantity of food and the numbers of copepods per fish in samples of young herring from the west coast of Denmark and found that feeding decreased during the night, i.e. from Io p.m. till Io a.m. Lissner (1925) dealing with adult herring in the North Sea concluded that they are attracted by a weak light, begin to feed in the afternoon and stop towards morning. Mužinić (I93I) found that feeding was at its maximum from about 5 p.m. to 9 p.m. and then slackened off till 4 or $5 \mathrm{a} . \mathrm{m}$. when there was a slight increase. This compares well with the feeding of the inshore herring from the Clyde (Fig. I2 A). Battle et al. (1936) state that young herring require a good light to feed by and that although moonlight is bright 
enough, starlight is not. For this reason the plankton present in the surface waters is most important for them.

We wish to thank the staff of the laboratory for their co-operation in the work. We are indebted to the Fishery Board for Scotland for the loan of a shore seine and for the herring reports obtained through their Fishery Officers in the Clyde; also to the Fisheries Laboratory, Lowestoft, for the loan of a shore seine and drift nets.

\section{SUMMARY}

Two groups of young herring are found in the Clyde. One, the offshore group, has been identified as Clyde spring-spawned herring; the other, the inshore type, is of unknown origin. The former were caught only occasionally, the latter at fairly regular intervals during their first year.

The two groups are distinguished by differences in size and identified as belonging to different races by vertebral counts. There was no intermixture.

The offshore herring which metamorphosed at the end of May when 40-50 mm. long, reached a length of 90-100 mm. in winter. The inshore fish which were about $50 \mathrm{~mm}$. long in May reached a length of about $130 \mathrm{~mm}$. in winter.

Equations are given showing the relation between length and weight for inshore and offshore herring during the growing and non-growing periods.

Determinations were made of water, fat, protein and ash content of inshore herring. The fat content rises during the summer and falls in winter. It varies inversely with the water content. The fat content continues to increase for some weeks after growth in length has stopped in winter and rises also in spring some time before increase in length begins again.

The food was examined throughout the year and compared with plankton hauls. It consisted mainly of copepods although other organisms were common at times when abundant in the plankton.

A series of hauls made over a night showed that herring were most abundant inshore at dusk and dawn and contained most food from 7-I I p.m.

\section{REFERENCES}

Battle, H. I., Huntsman, A. G., Jeffers, A. M., Jeffers, G. W., Johnson, W. H. \& MCNaIRN, N. A., I936. Fatness, digestion and food of Passamaquoddy young herring. Fourn. Biol. Board Canada, Vol. II, pp. 40I-29.

BRUCE, J. R., I924. Changes in the chemical composition of the tissues of the herring in relation to age and maturity. Biochem. Fourn., Vol. xviII, pp. 469-85.

Channon, H. J. \& El SABY, M. K., 1932. Fat metabolism of the herring. I. A preliminary survey. Biochem. Fourn., Vol. XxvI, pp. $202 \mathrm{I}-34$.

FoRD, E., I928a. Herring investigations at Plymouth. I. Methods of collection and treatment of data. Fourn. Mar. Biol. Assoc., Vol. xv, pp. 237-66. 
ForD, E., I928b. Ibid. III. The Plymouth winter fishery during the seasons I924-25, I925-26, and I926-27. Fourn. Mar. Biol. Assoc., Vol. xv, pp. 279-304.

I928c. Ibid. IV. The growth of young herrings in the neighbourhood of Plymouth. Fourn. Mar. Biol. Assoc., Vol. xv, pp. 305-I9.

- I933. The "number of vertebrae" in the herring and its variation. Fourn. Cons. Int. Explor. Mer., Vol. viII, pp. 2 I I-22.

- 1937. Vertebral variation in teleostean fishes. Fourn. Mar. Biol. Assoc., Vol. xxir, pp. I-6o.

FRASER, J. H., I93I. On the size of Urosalpinx cinerea (Say) with some observations on weight-length relationship. Proc. Malacol. Soc., Vol. xIx, pp. 243-54.

HaRdy, A. C., I924. The herring in relation to its animate environment. Part I. The food and feeding habits of the herring with special reference to the east coast of England. Min. Agric. Fish., Fish. Invest., Ser. II, Vol. viI, No. 3, pp. I-53.

Jespersen, P., I928. Investigations on the food of the herring in Danish waters. Medd. fra Komm. for Havunders., Ser. Plankton, Vol. II, No. 2, pp. I-I5O.

JoHANSEN, A. C., I9I9. On the large spring-spawning sea herring (Clupea harengus L.) in the north-west European waters. Medd. fra Komm. for Havunders., Ser. Fisk, Vol. v, No. 8, pp. I-56.

KÄNDLER, R., I932. Unsicherheiten bei Bestimmung der Wirbelzahl infolge Verwachsungserscheinungen. Fourn. Cons. Int. Explor. Mer., Vol. vII, pp. 373-85.

LEA, E., I9IO. On the methods used in herring investigations. Cons. Int. Explor. Mer., Publ. de Circ., No. 53, pp. 7-I74.

- Igri. A study on the growth of herrings. Cons. Int. Explor. Mer., Publ. de Circ., No. 61, pp. 35-48.

Lissner, H., I925. Die Nahrungsaufnahme beim Hering. Ber. Deutsch. wiss. Komm. f. Meeresf., N.F., Bd. I, pp. 199-208.

LOVERN, J. A. \& WooD, H., I937. Variations in the chemical composition of herring. fourn. Mar. Biol. Assoc., Vol. xxir, pp. 28I-93.

Marshall, S. M., Nicholls, A. G., \& ORR, A. P., I934. On the biology of Calanus finmarchicus. V. Seasonal distribution, size, weight and chemical composition in Loch Striven in 1933, and their relation to the phytoplankton. Fourn. Mar. Biol. Assoc., Vol. xIx, pp. 793-828.

I937. On the growth and feeding of the larval and post-larval stages of the Clyde herring. Fourn. Mar. Biol. Assoc., Vol. xxiI, pp. 245-67.

MEYeR, H. A., 1878. Beobachtungen über das Wachsthum des Herings im westlichen Theile der Ostsee. Fahresbericht der Komm. z. wiss. Unters. der deutschen Meere in Kiel, 4.-6. Jahrg., pp. 227-52.

MuŽINIĆ, S., I93I. Der Rhythmus der Nahrungsaufnahme beim Hering. Ber. Deutsch. wiss. Komm. f. Meeresf., N.F., Bd. vI, pp. 62-4.

OGILVIE, H. S., I934. A preliminary account of the food of the herring in the northwestern North Sea. Rapp. Proc.-Verb. Cons. Int. Explor. Mer., Vol. Lxxxix, Pt. 3, pp. 85-92.

Orton, J. H., I9I6. An account of the researches on races of herrings carried out by the Marine Biological Association at Plymouth I9I4-I5. Fourn. Mar. Biol. Assoc., Vol. XI, pp. 7I-I2I.

EL SABY, M. K., I932. The number of vertebrae in summer-spawning Manx herring. 40th Ann. Rep. Lancashire Sea-fish. Lab., pp. I39-48.

Savage, R. E., I937. The food of North Sea herring I930-1934. Min. Agric. Fish., Fish. Invest., Ser. II, Vol. xv, No. 5, pp. I-6o.

Scotr, T., 1907. Some observations on the food of the herring. 25th Ann. Rep. Fish. Bd. Scotland (I906), Pt. III, No. vi, pp. 260-7I.

WaIles, G. H., I936. Food of Clupea pallasii in southern British Columbia waters. Fourn. Biol. Board Canada, Vol. I, pp. 477-86. 
Williamson, H. C., I9I4. A short résumé of the researches into the European races of herrings and the method of investigation. Fisheries, Scotland, Sci. Invest., I914, No. I, pp. I-22.

Wood, H., 1936. Race investigation of the herring population of Scottish waters. Fisheries, Scotland, Sci. Invest., I936, No. III, pp. I-52.

- 1937. Movements of herring in the northern North Sea. Fisheries, Scotland, Sci. Invest., 1937, No. III, pp. I-49. 